\title{
Abundance and dynamics of microplankton in the central tropical Indian Ocean
}

\author{
Yu. I. Sorokin, A. I. Kopylov, \& N. V. Mamaeva \\ South Department of the Institute of Oceanology, Academy of Sciences, USSR, Gelendzhik 7 Krasnodar District, 353470 USSR
}

\begin{abstract}
In the central part of the Indian Ocean, primary production and quantitative distribution of microheterotrophs were studied in August-September. Ptimary production in areas of divergence and in waters of the Trade Wind Current was high $\left(0.3\right.$ to $\left.1.5 \mathrm{~g} \mathrm{C} \mathrm{m}^{-2} \mathrm{~d}^{-1}\right)$. At some stations, at the water surface it was up to 15 to $20 \mathrm{mg} \mathrm{C} \mathrm{m}^{-3} \mathrm{~d}^{-1}$. In areas of convergence it decreased 0.1 to $0.2 \mathrm{~g}$ $\mathrm{C} \mathrm{m}^{-2} \mathrm{~d}^{-1}$ ). Deep maxima of accumulation of active phytoplankton were recorded at the upper boundary of the thermocline. Total number of bacteria in the euphotic zone varied from 6 to $15 \times 10^{4}$ $\mathrm{ml}^{-1}$, biomass from 10 to $30 \mathrm{mg} \mathrm{m}^{-3}$ (wet weight), production and respiration from 5 to $15 \mathrm{mg} \mathrm{m}^{-3} \mathrm{~d}^{-1}$, and from 3 to $10 \mathrm{mg} \mathrm{O} \mathrm{O}^{-1}$, respectively. Below $200 \mathrm{~m}$ the above parameters decreased 1 order of magnitude or more. The amounts of 'olive cells' found at depths of 200 to $2000 \mathrm{~m}$ varied from 60 to 400 $\mathrm{ml}^{-1}$. Observations suggest that 'olive cells' represent cysts of microflagellates inhabiting deep waters. Species composition, total number, biomass, patterns of vertical distribution and diumal dynamics of planktonic protozoans (zooflagellates, ciliates) are described. Numbers of nauplii and Radiolaria as components of microzooplankton are given. Functional roles of the main groups of microplankton in pelagic communities of the tropical oceanic waters investigated are evaluated via energy-flow schemes.
\end{abstract}

\section{INTRODUCTION}

The functional activity of microplanktonic organisms (phytoplankton, planktonic bacteria, microzooplankton) can be regarded a main factor in the basic food sources in the oceans, in addition to playing key roles in the cycling of organic matter and in nutrient regeneration (Pomeroy 1974, Sieburth et al. 1978, Sorokin 1978, 1981, Eppley 1981). Of the activities of microplankton in the Indian Ocean, only the primary phytoplankton production was measured by several investigators (Kabanova 1963, Ryther et al. 1966, Aruga 1971, Krey 1973, Kabanova \& Borodkin 1981, Kuzmenko 1981). Even those measurements were made mostly in coastal or peripheric areas, in particular in the north-western parts of the Indian Ocean, the Arabian Sea and the Gulf of Aden (Kabanova 1968). Data on primary phytoplankton in the central parts of tropical Indian Ocean are scarce (Koblentz-Mischke et al. 1970). Moreover, the data available were obtained by employing not very reliable modifications of the radiocarbon technique, failing to account for the loss of a large portion of fixed ${ }^{14} \mathrm{C}$ during filtration, as well as for the flaky character of the vertical structure of phyto- plankton communities in the stratified water column of tropical waters (Sorokin 1960, 1971).

In regard to planktonic microheterotrophs, such as bacteria amd microzooplankton, data for the central tropical Indian Ocean are still practically absent. Several estimates of the total number of bacteria made by Mitzkevich \& Kriss (1982) cannot be regarded as reliable. These authors counted bacteria in a chamber, filled with samples previously concentrated with the aid of membrane filters. During this procedure 80 to $90 \%$ of the total bacteria remained clogged at the filter surface. The bacteria could not be washed out by the procedure used by the authors. As for microzooplankton there are only a few, mostly qualitative, data on tintinnids in coastal waters of the Indian Ocean (Prasad 1956, Zeitzschel 1969, Krishnamurthy \& Santhanam 1975). In tropical waters, tintinnids compose usually only a minor portion populations of planktonic protozoans (Sorokin 1981). For naked ciliates and for zooflagellates, which actually form the bulk of the protozooplankton biomass, no data are available.

During the 25th cruise of RV 'Dmitri Mendeleev' in August-September 1981 we measured primary production, total numbers, biomass and production of 
planktonic bacteria in the central pelagic parts of the Indian Ocean. Simultaneously, species composition as well as number and biomass of the main groups of microzooplankton were estimated. Special attention was paid to the description of the vertical community of microplankton and of its activity within the water column as a function of thermal stratification.

\section{METHODS}

The studies were carried on a section along $80^{\circ} \mathrm{E}$, in the area of the Carlsberg Ridge and in the area of the Triple Point. Thus these areas included the waters of the main surface currents of the tropical Indian Ocean: the Moonson Current, South Trade and Intertrade Currents, as well as the areas of the South Tropical Divergence and the South Tropical Convergence. Fig. 1 illustrates the position of the stations.

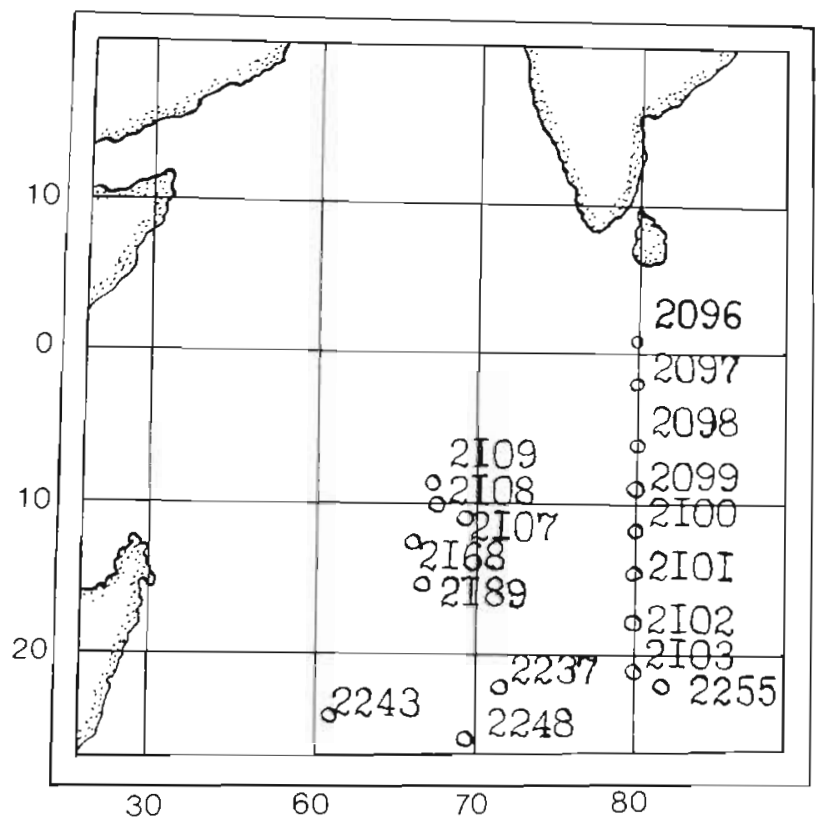

Fig. 1. Position of stations in the central Indian Ocean

Water samples were taken with 71 plastic bottles. Sampling depths were selected at each station after previously recording the temperature over 0 to $200 \mathrm{~m}$ in order to locate the most microplankton maximum. As shown in our previous investigations (Sorokin 1960 . 1971,1981 ) the layer of maximum is usually situated in the upper part of the thermocline. Within the layer of the maximum, samples were taken at shorter intervals in order to avoid missing the main maximum. Within the layer 0 to $200 \mathrm{~m}, 10$ to 15 samples were taken over a vertical profile. The exact depth of sampling below 200 $m$ was checked by employing a thermo-depth meter
Primary phytoplankton production was measured using the radiocarbon method developed by Steeman Nielson in its modified version (simulated in situ method) described by Sorokin $(1960,1971,1973)$. All experiments were performed in bottles of 0.571 capacity. The 'working' solution of ${ }^{14} \mathrm{C}$ carbonate was prepared by passing ${ }^{14} \mathrm{C}$ through the $\mathrm{CO}_{2}$-gas phase in order to clean the commercial ${ }^{14} \mathrm{C}$ carbonate preparation. The labelled $\mathrm{CO}_{2}$ was dissolved in alkaline $4 \%$ $\mathrm{NaCl}$ solution and its $\mathrm{pH}$ adjusted to 9.5. It was filtered via $0.1 \mu \mathrm{m}$ pore-size membrane filters and sterilized in sealed ampoules by double boiling at an interval of $1 \mathrm{~d}$. Actual radioactivity was $3 \times 10^{7} \mathrm{cpm} \mathrm{ml} \mathrm{min}^{-1}$. It was measured by insertion of $0.02 \mathrm{ml} \mathrm{1:100} \mathrm{solution} \mathrm{on} \mathrm{the}$ surface of the membrane filter moistened with $1 \%$ alcaline $\mathrm{BaCl}_{2}$ solution. The filter was then placed in a vial with scintillation liquid, and its radioactivity was measured instantly employing the portable counter 'Coruflow' (Intertracelab). For details consuit Sorokin (1971, 1973).

To measure primary production in the water column under $1 \mathrm{~m}^{2}, \mathrm{~K}_{\mathrm{p}}$ coefficients (relative photosynthetic activity of phytoplankton in the water column) were estimated at every station in samples taken at different depths and incubated at temperate illumination (25\% natural illumination) for 2 to $3 \mathrm{~h} . \mathrm{K}_{\mathrm{t}}$ coefficients (dependence of phytoplankton photosynthesis on light conditions in the water column), being quite similar to oceanic waters with corresponding levels of primary production, were used for these estimations (source: Sorokin 1960,1963, 1964, 1973).

Total number of planktonic bacteria and their biomasses were measured by direct microscopic counts on membrane filters (SYNPOR-8) with pore sizes ranging from 0.1 to $0.2 \mu \mathrm{m}$. Bacteria on filters were stained with erythrosin (Sorokin 1971, Sorokin \& Kadota 1972). Simultaneously 'olive cells' (detected by Hentschel 1936; later studied by Fournier 1970) were counted. For these counts, water samples $(100$ to $300 \mathrm{ml})$ were filtered through membrane filters. Non-stained filters were cleared with immersion oil and examined under a phase-contrast microscope.

Microbial production was measured using the radiocarbon method (Romanenko 1964, Sorokin 1971). Water samples were prefiltered for analysis through a $10 \mu \mathrm{m}$ net to remove the major parts of phyto- and zooplankton. Experiments were performed in bottles $(250 \mathrm{ml})$ previously sterilized by rinsing with acid iodine solution. Before use the bottles were rinsed carefully with water from the same sample. Bottles filled with prefiltered water were kept for $2 \mathrm{~h}$ in the dark: then portions of ${ }^{14} \mathrm{C}$-carbonate solution were added. Samples fixed with iodine solution served as controls. Actual radioactivity of ${ }^{14} \mathrm{C}$-carbonate added samples was $20 \times 10^{6} \mathrm{dpm} \mathrm{min}^{-1}$. After $1 \mathrm{~d}$ exposure 
they were filtered through membrane filters of 0.2 to $0.3 \mu \mathrm{m}$ pore size. Filters were processed after filtration in the same way as described above.

Microbial production (P) was calculated as follows:

$$
P=\frac{r \times K \times 150 \times 10^{3}}{R}
$$

$\mathrm{mg} \mathrm{m}^{-3}$ wet biomass, containing $10 \%$ of organic carbon where $\mathrm{r}=$ radioactivity of filter (subtracting control); $\mathrm{K}=$ carbonate carbon in sea water, $\mathrm{mg} \mathrm{C} \mathrm{m}^{-1} ; \mathrm{R}=$ radioactivity of the portion of ${ }^{14} \mathrm{C}$-carbonate solution inserted into the bottle. To measure microbial production in water samples taken below 200 to $300 \mathrm{~m}$, these were incubated at in situ temperatures. Deep-water samples were incubated at in situ temperatures for 3 to $6 \mathrm{~d}$, and triple portions of ${ }^{14} \mathrm{C}$-carbonate solution were added to them in order to increase the sensitivity of estimations. The inhibiting influence of pressure upon the microbial metabolism in deep water (e.g. Morita 1972) was also accounted for during calculation of microbial production in those samples. All data on microbial biomass and production presented in the tables are units of wet biomass containing $10 \%$ carbon.

Rate of bacterioplankton respiration was calculated from data on microbial production, accepting that (1) carbon contents in the microbial biomass are equal to $10 \%$ (Troitsky \& Sorokin 1967); (2) efficiency coefficient $\mathrm{K}_{2}$ of microbial production (use of consumed food for growth) is equal to 0.32 in natural sea water bacterioplankton (Sorokin \& Kogelschatz 1979); (3) the respiration coefficient is equal to 1 . Then, microbial respiration (M) will be equal to:

$$
\mathrm{M}=\mathrm{P} \times 0.56 \mu \mathrm{g} \mathrm{O} \mathrm{I}^{-1} \mathrm{~d}^{-1}
$$

where $\mathrm{P}=$ microbial production in $\mu \mathrm{g} \mathrm{l}^{-1} \mathrm{~d}^{-1}$ (wet weight).

Relative microbial activity on vertical profiles was measured with the use of labelled dissolved organic matter (algal proteinten Tat. Ein Porträt der $s$ of its solution ( 3 to $5 \mu \mathrm{g} \mathrm{C}$ ) were added to $250 \mathrm{ml}$ samples taken in sterile bottles at constant $20^{\circ} \mathrm{C}$. After 8 to $10 \mathrm{~h}$ of exposure the ${ }^{14} \mathrm{C}$ radioactivity consumed by bacteria was measured, and its level was used as indicator of relative microbial activity in the sample (Sorokin 1970). In the series of samples taken on vertical profiles the potential microbial production was also measured as indicator of the relative stock of labile organic matter accessible to microbial action (Sorokin 1971, 1973). Microbial production was measured in a series of samples taken on a vertical profile by incubating all samples at $25^{\circ} \mathrm{C}$ for 3 to $4 \mathrm{~d}$. In this case the resulting microbial production depends mostly on the content of available labile organic matter in the initial water.
To calculate the biomass, number and size of cells of phagotrophic zooflagellates were counted in the subsamples taken carefully through the upper valve of a plastic water bottle in order to prevent mechanical damage to these organisms. Samples were examined 15 to 20 min after arrival of the water bottle. Samples of the vertical profile were taken and processed under the microscope one after another. Delay in counts of more than $1 \mathrm{~h}$ causes a large decrease in the numbers of zooflagellates. The zooflagellates were counted in a glass chamber with a volume of $4 \mathrm{ml}$ ( $25 \mathrm{~mm}$ wide, 100 $\mathrm{mm}$ long, $1.7 \mathrm{~cm}$ deep; Sorokin 1977, 1980). The filled chamber was immediately inspected under the phasecontrast microscope. At a magnification of $125 \times, 10$ to 80 fields were examined, depending upon the abundance of zooflagellates in the sample. In addition to free-living zooflagellates, those attached to detritus and to phytoplankton cells were counted in the nonfixed samples concentrated immediately after sampling from 3 to $5 \mathrm{l}$ to 30 to $40 \mathrm{ml}$ by gentle reverse filtration in a special funnel (Fig. 2) using the Nuclepore filter $(1 \mu \mathrm{m}$ pore size, $8 \mathrm{~cm}$ diameter; Sorokin 1979).

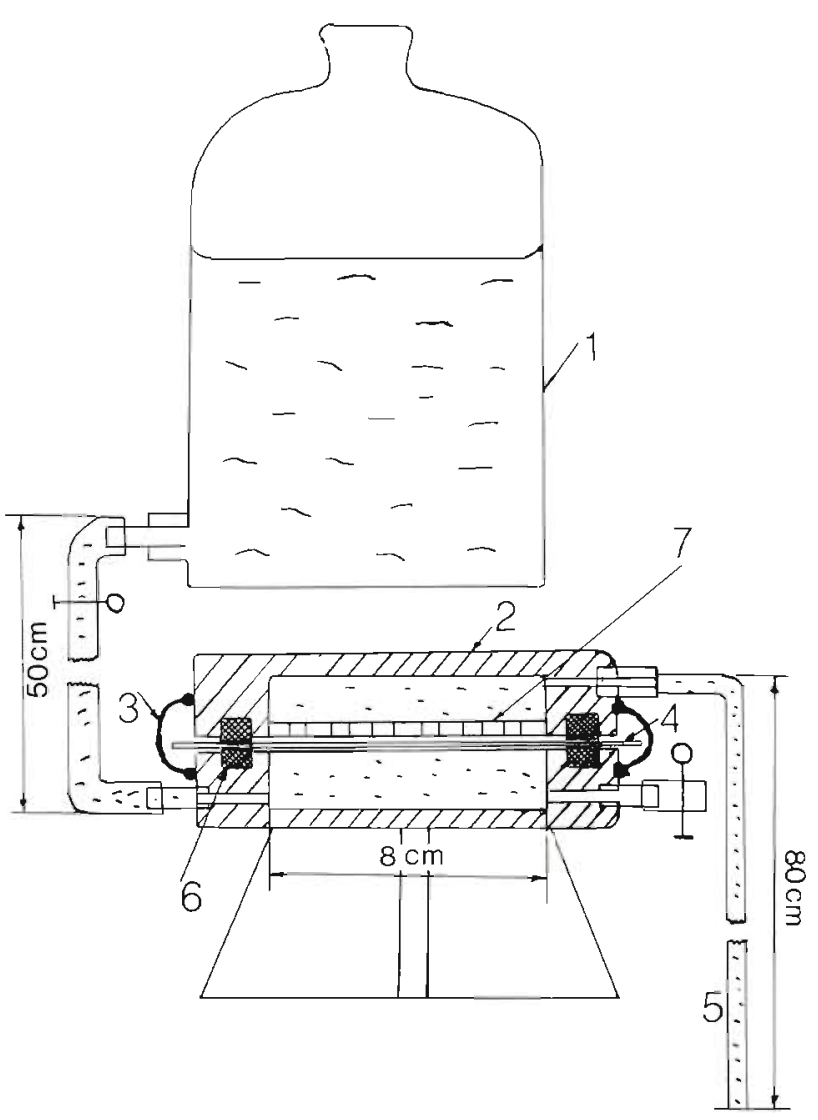

Fig. 2. Device for reverse filtration for concentrating microplankton on Nuclepore filter: 1: sample; 2: funnel; 3: clamp; 4: filter; 5: discharge; 6 : rubber ring; 7 : supporting perforated plate 
Counting and sizing of planktonic ciliates was accomplished by the method described above for zooflagellates. Intact samples were examined immediately with a stereoscope at $50 \times$ in a $25 \mathrm{ml}$ chamber (length: $105 \mathrm{~mm}$; width: $60 \mathrm{~mm}$; depth: $4 \mathrm{~mm}$ ). Total sample volume varied from 25 to $100 \mathrm{ml}$, depending on the abundance of ciliates. For sizing and identification, single specimens of ciliates were caught in the chamber under the stereoscope with the aid of a fine pipette, transfered to a small chamber $(0.3 \mathrm{~mm}$ depth) and examined unter the microscope. By this method naked ciliates and small tintinnids were counted. Larger microzooplankton with skeleton (larger tintinnids, radiolarians, nauplii) survived the concentration procedure and were counted in the above-mentioned concentrated samples soon after finishing the concentration procedure.

\section{RESULTS}

\section{Vertical destribution of active phytoplankton and primary production}

Results of our estimations are presented in Table 1 and 2, and in Fig. 3 to 6 . These data show that in the

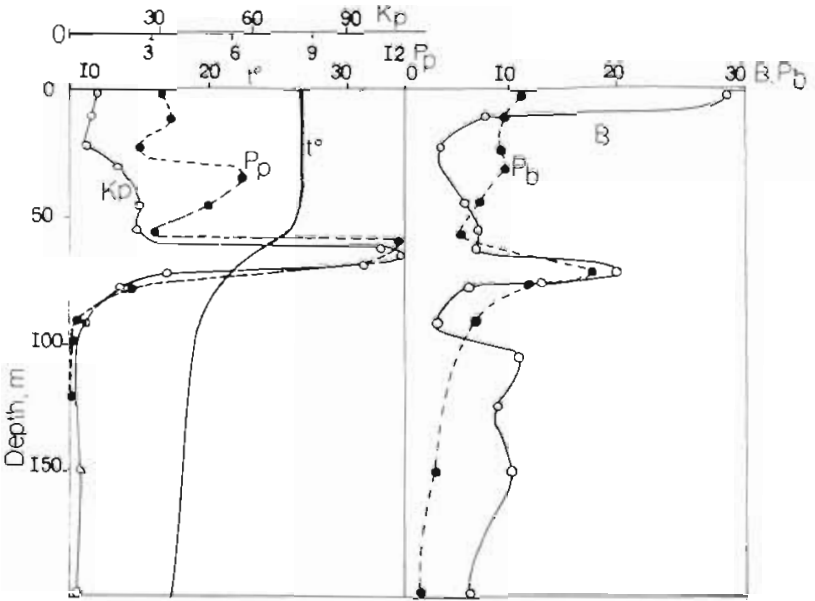

Fig. 3. Distribution in the water column at Station 2097 (Moonson Current) of temperature $\left(\mathrm{t}^{\circ}\right)$, active phytoplankton

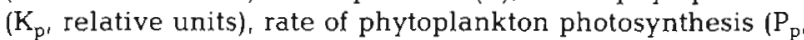
$\left.\mathrm{mg} \mathrm{C} \mathrm{m}^{-3} \mathrm{~d}^{-1}\right)$; and of biomass and bacterioplankton production ( $\mathrm{B}$ and $\mathrm{P}_{\mathrm{b}}, \mathrm{mg} \mathrm{m}^{-3}$, wet weight)

stratified waters of the Moonson and of the Trade Wind Currents, deep maxima of active phytoplankton exist. The vertical distribution of active phytoplankton corresponds to the variation of $\mathrm{K}_{\mathrm{p}}$-coefficients within the

Table 1. Vertical distributions of active phytoplankton $\left(K_{p}\right.$, relative values), photosynthesis rate $\left(P_{p}, m^{-3} \mathrm{~m}^{-3} \mathrm{~d}^{-1}\right)$, bacterioplankton numbers $\left(\mathrm{N}, 10^{3} \mathrm{ml}^{-1}\right)$, wet biomasses $\left(B, \mathrm{mg} \mathrm{m} \mathrm{m}^{-3}\right)$, and phytoplankton production per day $\left(\mathrm{P}_{\mathrm{b}}, \mathrm{mg} \mathrm{m}^{-3}\right)$ at 3 stations on the cross section along $80^{\circ} \mathrm{E}$.

\begin{tabular}{|c|c|c|c|c|c|c|c|c|c|c|c|c|c|c|c|c|c|}
\hline \multirow{3}{*}{$\begin{array}{l}\text { Depth } \\
\text { (m) }\end{array}$} & \multicolumn{5}{|c|}{ Station 2096} & \multicolumn{6}{|c|}{ Station 2099} & \multicolumn{6}{|c|}{ Station 2103} \\
\hline & \multicolumn{2}{|c|}{$\begin{array}{l}\text { Phyto- } \\
\text { plankton }\end{array}$} & \multicolumn{3}{|c|}{$\begin{array}{l}\text { Bacterio- } \\
\text { plankton }\end{array}$} & \multirow[t]{2}{*}{$\begin{array}{l}\text { Depth } \\
\text { (m) }\end{array}$} & \multicolumn{2}{|c|}{$\begin{array}{l}\text { Phyto- } \\
\text { plankton }\end{array}$} & \multicolumn{3}{|c|}{$\begin{array}{l}\text { Bacterio- } \\
\text { plankton }\end{array}$} & \multirow[t]{2}{*}{$\begin{array}{c}\text { Depth } \\
\text { (m) }\end{array}$} & \multicolumn{2}{|c|}{$\begin{array}{l}\text { Phyto- } \\
\text { plankton }\end{array}$} & \multicolumn{3}{|c|}{$\begin{array}{l}\text { Bacterio- } \\
\text { plankton }\end{array}$} \\
\hline & $\mathrm{K}_{\mathrm{p}}$ & $\mathrm{P}_{\mathrm{p}}$ & $\mathrm{N}$ & B & $P_{b}$ & & $\mathrm{~K}_{\mathrm{p}}$ & $P_{p}$ & $\mathrm{~N}$ & B & $\mathrm{P}_{\mathrm{b}}$ & & $\mathrm{K}_{\mathrm{p}}$ & $P_{p}$ & $\mathrm{~N}$ & $B$ & $P_{\mathrm{b}}$ \\
\hline 0 & 1.0 & 9.2 & 106 & 21 & 16.9 & 0 & 1.0 & 7.0 & 47 & 14 & 11.2 & 0 & 1.0 & 2.8 & 28 & 6 & 6.9 \\
\hline 25 & 0.41 & 15.2 & 37 & 4 & 5.8 & 20 & 1.5 & 14.1 & 91 & 18 & 10.1 & 20 & 0.21 & 0.8 & 43 & 5 & 7.6 \\
\hline 56 & 1.85 & 13.1 & 110 & 17 & 12.3 & 45 & 0.95 & 7.0 & 39 & 8 & 6.2 & 30 & 0.45 & 1.5 & 66 & 9 & 9.2 \\
\hline 63 & 4.0 & 19.3 & 64 & 10 & 8.2 & 60 & 3.1 & 12.0 & 110 & 22 & 13.4 & 60 & 0.2 & 0.3 & 68 & 10 & 7.6 \\
\hline 70 & 1.83 & 6.8 & 183 & 37 & 13.5 & 64 & 6.2 & 21.0 & 140 & 34 & 8.1 & 90 & 2.0 & 1.1 & 80 & 12 & 3.3 \\
\hline 90 & 0.36 & 0.6 & 27 & 4 & 2.6 & 90 & 1.18 & 1.6 & 110 & 17 & 3.3 & 110 & 4.6 & 0.8 & 140 & 28 & 5.1 \\
\hline 120 & 1.18 & 0.07 & 55 & 10 & 8.1 & 120 & 0.6 & 0.2 & 43 & 8 & 1.1 & 130 & 3.6 & 0.3 & 55 & 6 & 1.3 \\
\hline
\end{tabular}

Table 2. Parameters of phytoplankton and bacterioplankton distributions in the water column at 3 stations in the area of the Trenches and of the Triple Point. For explanation see Table 1

\begin{tabular}{|c|c|c|c|c|c|c|c|c|c|c|c|c|c|c|c|c|c|}
\hline \multirow{3}{*}{$\begin{array}{l}\text { Depth } \\
\text { (m) }\end{array}$} & \multicolumn{5}{|c|}{ Station 2109} & \multicolumn{6}{|c|}{ Station 2189} & \multicolumn{6}{|c|}{ Station 2248} \\
\hline & \multicolumn{2}{|c|}{$\begin{array}{l}\text { Phyto- } \\
\text { plankton }\end{array}$} & \multicolumn{3}{|c|}{$\begin{array}{l}\text { Bacterio- } \\
\text { plankton }\end{array}$} & \multirow[t]{2}{*}{$\begin{array}{l}\text { Depth } \\
\text { (m) }\end{array}$} & \multicolumn{2}{|c|}{$\begin{array}{l}\text { Phyto- } \\
\text { plankton }\end{array}$} & \multicolumn{3}{|c|}{$\begin{array}{l}\text { Bacterio- } \\
\text { plankton }\end{array}$} & \multirow[t]{2}{*}{$\begin{array}{l}\text { Depth } \\
\text { (m) }\end{array}$} & \multicolumn{2}{|c|}{$\begin{array}{l}\text { Phyto- } \\
\text { plankton }\end{array}$} & \multicolumn{3}{|c|}{$\begin{array}{l}\text { Bacterio- } \\
\text { plankton }\end{array}$} \\
\hline & $\mathrm{K}_{\mathrm{p}}$ & $P_{p}$ & $N$ & $B$ & $P_{b}$ & & $K_{\mathrm{p}}$ & $\mathrm{P}_{\mathrm{p}}$ & $N$ & $\mathrm{~B}$ & $\mathrm{P}_{\mathrm{b}}$ & & $\mathrm{K}_{\mathrm{p}}$ & $P_{p}$ & $N$ & $\mathrm{~B}$ & $P_{b}$ \\
\hline 0 & 1.0 & 32.1 & 90 & 18 & 11.6 & 0 & 1.0 & 6.7 & 110 & 17 & 11.8 & 0 & 1.0 & 1.9 & 55 & 8 & 5.6 \\
\hline 20 & 0.6 & 25.7 & 93 & 19 & 6.9 & 20 & 1.0 & 9.0 & 72 & 11 & 4.5 & 20 & 1.0 & 2.5 & 74 & 15 & 18.2 \\
\hline 50 & 0.45 & 7.1 & 226 & 68 & 23.8 & 50 & 0.6 & 2.7 & 112 & 11 & 2.7 & 40 & 1.6 & 4.1 & 92 & 11 & 7.9 \\
\hline 62 & 0.6 & 58.0 & 332 & 134 & 25.3 & 75 & 1.1 & 2.7 & 88 & 9 & 6.7 & 50 & 2.1 & 3.1 & 55 & 7 & 4.2 \\
\hline 64 & 2.6 & 25.0 & 335 & 205 & 31.3 & 100 & 2.3 & 1.5 & 50 & 10 & 2.2 & 70 & 2.7 & 1.9 & 43 & 5 & 3.2 \\
\hline 75 & 0.1 & 0.6 & 64 & 16 & 5.4 & 120 & 0.5 & 0.14 & 85 & 25 & 4.9 & 100 & 1.5 & 0.3 & 92 & 14 & 1.7 \\
\hline 120 & 0.1 & 0.04 & 32 & 10 & 1.2 & 150 & 0.3 & 0 & 26 & 3 & 0.4 & 130 & 0.6 & 0.04 & 74 & 9 & 0.9 \\
\hline
\end{tabular}


Fig. 4. Distribution in the water column at Station 2108 (South Trade Wind Current, Vema Trench) of some parameters of activity and microplankton biomass; for explanation see Fig. 3

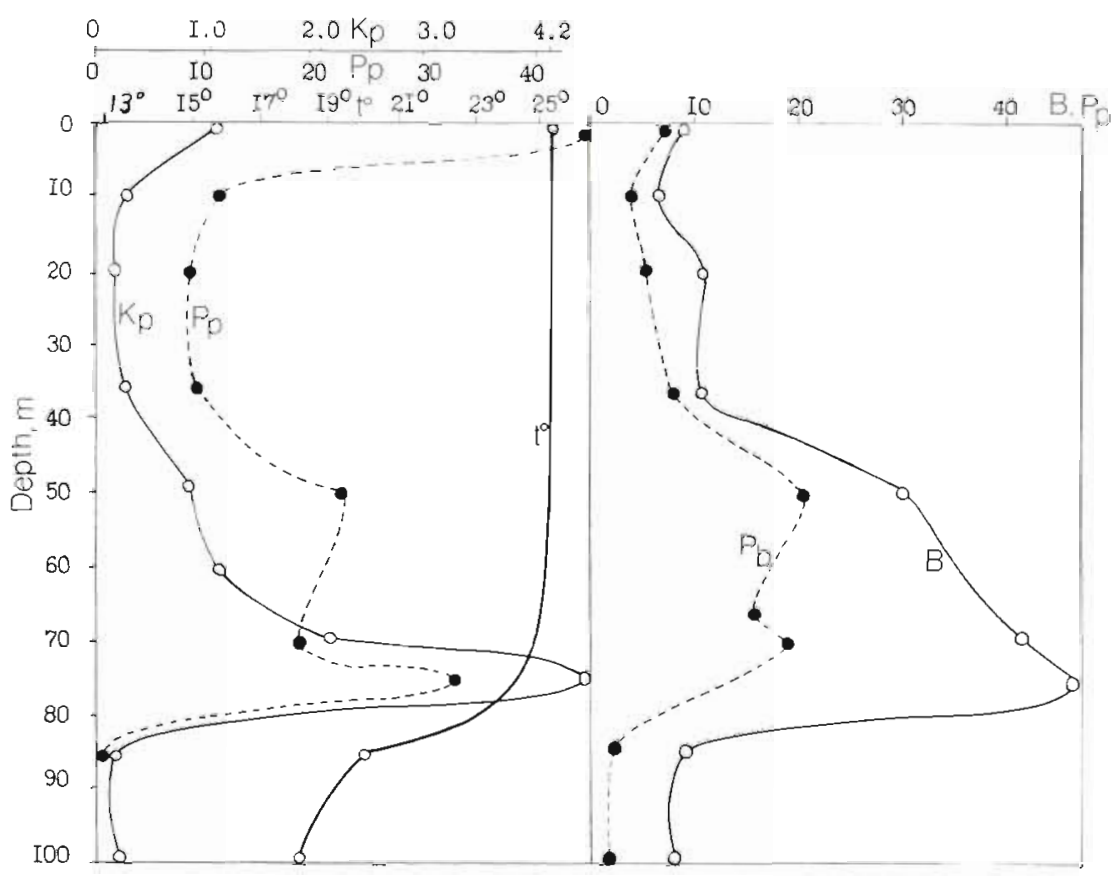

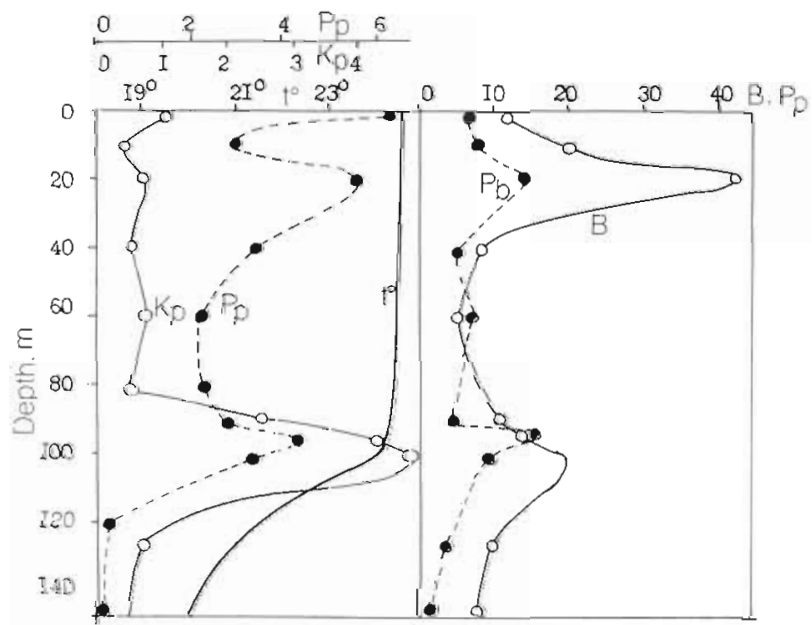

Fig. 5. Distribution in the water column at Station 2168 (Trade Wind Current, Argo trench) of some parameters of activity and biomass of microplankton; for explanation see Fig. 3

water column (Sorokin 1964). Maxima of $K_{p}$ were situated at the upper boundary of the thermocline. At some stations the concentrations of living phytoplankton in the layers of these maxima, in accordance with $\mathrm{K}_{\mathrm{p}}$ values, exceed those near the surface 4 to 10 times. In areas of the Moonson Current, of the Equatorial Countercurrent ( 1 to $\left.5^{\circ} \mathrm{S}\right)$, and of the South Tropical Divergence $\left(5\right.$ to $\left.7^{\circ} \mathrm{S}\right)$ the upper boundary of the thermocline was relatively shallow (55 to $65 \mathrm{~m}$ depth). At these depths (St. 2096, 2097), active phytoplankton and even the absolute rates of photosynthesis were maximal. Photosynthesis rates in this layer ranged from 13 to 19 $\mathrm{mg} \mathrm{C} \mathrm{m}{ }^{-3}$, thus corresponding to rates in mesotrophic oceanic surface waters.
Primary production in the water column under $1 \mathrm{~m}^{2}$ also corresponded in this area to the level in mesotrophic waters $\left(0.3\right.$ to $0.8 \mathrm{~g} \mathrm{C} \mathrm{d}^{-1}$; Table 8$)$.

In areas of the South Tropical Divergence and in the Trade Wind Current between 7 and $17^{\circ} \mathrm{S}$ (St. 2097-2102 and 2108) the boundary of the thermocline decended to 60 to $80 \mathrm{~m}$. Phytoplankton maxima also decended to this layer (Tables 1 \& 2; Fig. 3 \& 4). Absolute rates of photosynthesis at these stations revealed 2 maxima, one in the layer of the optimum illumination for phytoplankton (20 to $30 \mathrm{~m}$ depth), and one at the boundary of the thermocline. Primary production values in Trade Wind Current areas along $80^{\circ}$ E ranged from 0.2 to $0.9 \mathrm{~g} \mathrm{C} \mathrm{m}^{-2} \mathrm{~d}^{-1}$ (Table 8).

At Stations 2108, 2109 and 2168 (Table 2; Fig. 4) in the area of deep trenches Argo and Vema the upper boundary of the thermocline was deep $(70$ to $80 \mathrm{~m}$ ). Nevertheless, primary production rates here were also relatively high: 5 to $30 \mathrm{mg} \mathrm{C} \mathrm{m} \mathrm{Cd}^{-1}$ at the surface and 3 to $4 \mathrm{mg}$ at 70 to $80 \mathrm{~m}$ depth in the layer of the phytoplankton maximum. Primary production under $1 \mathrm{~m}^{2}$ in this area was at the mesotrophic level: 0.4 to 1.5 $\mathrm{g} \mathrm{C} \mathrm{m}^{-3} \mathrm{~d}^{-1}$. The same high level of primary production (9 to $14 \mathrm{mg} \mathrm{C} \mathrm{m}^{-3} \mathrm{~d}^{-1}$ at the surface) was found at Station 2243, south of the South Tropical Convergence in waters of the South Indo-oceanic Current.

At Stations 2103, 2237 and 2255, at the Triple Point in waters of the South Tropical Convergence, the upper boundary of the thermocline was below $100 \mathrm{~m}$ near the lower boundary of the euphotic zone. The phytoplankton which inhabits this layer is inhibited by light deficiency. The maximum of primary production was situated here in the surface layer (3 to $4 \mathrm{mg}$ 


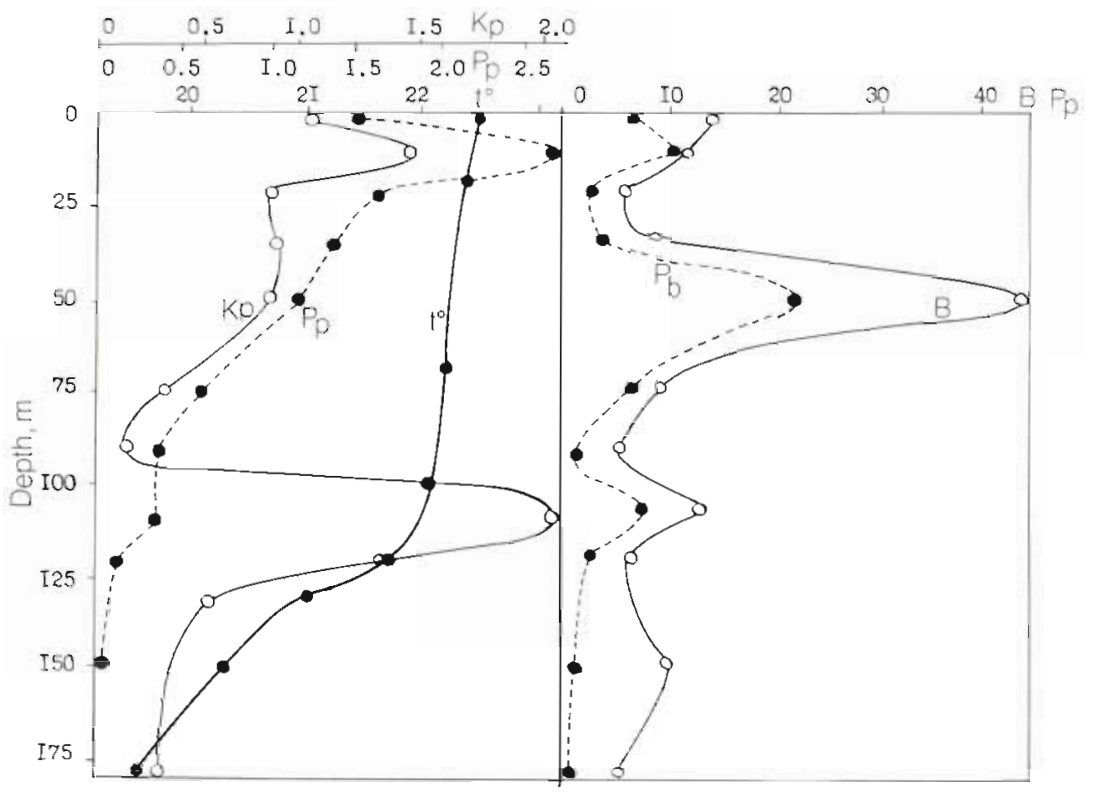

Fig. 6. Distribution in the water column at Station 2237 of some paraneters of activity and biomass of microplankton; for explanation see Fig. 3
$\mathrm{C} \mathrm{m}^{-3} \mathrm{~d}^{-1}$ ). The primary production in water column, 0.1 to $0.2 \mathrm{~g} \mathrm{C} \mathrm{m}^{-2} \mathrm{~d}^{-1}$, corresponded to the level of oligotrophic oceanic waters.

\section{Planktonic bacteria}

Estimations for the section along $80^{\circ} \mathrm{E}$ are presented in Table 1 and in Fig. 3. Maximum microbial numbers and biomasses were found in the area of the Equatorial Divergence (St. 2096 to 2098). In the vertical profiles, the first maximum was located near the surface; the second, at the thermocline boundary. In these layers the total number of bacteria exceeded $15 \times 10^{4} \mathrm{ml}^{-1}(18$ to $\left.46 \times 10^{4}\right)$. Bacterial biomass in these layers varied from 40 to $100 \mathrm{mg} \mathrm{m}^{-3}$, corresponding to the level of mesotrophic waters (Sorokin 1974). Average total numbers of planktonic bacteria in the euphotic zone were here 6 to $15 \times 10^{4} \mathrm{ml}^{-1}$ and biomasses 10 to $30 \mathrm{mg} \mathrm{m}^{-3}$. The numbers and biomasses of bacterioplankton were found in waters of the South Trade Wind Currents in the area of the trenches Vema and Argo (Table 2; Fig. 4 $\& 5)$. The maxima of the bacterioplankton in these waters were situated at the upper boundary of the thermocline, where its biomass ranged from 100 to $200 \mathrm{mg} \mathrm{m}^{-3}$.

At the stations south of the Trade Wind Current in the waters of the convergence at 20 to $22^{\circ} \mathrm{S}$ (St. 2237. $2255)$ the bacterioplankton was much more scarce $(25$ to $150 \times 10^{3} \mathrm{ml}^{-1}$ ). Usually 2 maxima of microbial numbers were found here: the first at the surface and the second at 130 to $150 \mathrm{~m}$ depth at the thermocline boundary. The average biomass of bacterioplankton ranged here from 5 to $15 \mathrm{mg} \mathrm{m}^{-3}$. In the layers of maxima it increased up to 30 to $40 \mathrm{mg} \mathrm{m}^{-3}$ (Table 2; Fig. 6).
The microbial production attained its maximum also in the waters of the Trade Wind Current and of the Equatorial Divergence. Its maximum values $(10$ to $35 \mathrm{mg} \mathrm{m}^{-3} \mathrm{~d}^{-1}$ ) were found in the upper layer and in the layer of the main microplankton maximum at the upper boundary of the thermocline (Tables $1 \& 2$; Fig. 3 to 6). Its average values within the euphotic zone ranged from 5 to $15 \mathrm{mg} \mathrm{m}^{-3}$. $\mathrm{P} / \mathrm{B}$ coefficients in the upper mixed layer varied from 0.6 to $1.2 \mathrm{~d}^{-1}$. Below the upper boundary of thermocline they decreased to 0.3 to 0.6 . In the oligotrophic waters of convergence (St. 2103, $2237,2255)$ the production of bacteria within the euphotic zone was only 3 to $10 \mathrm{mg} \mathrm{m}^{-3} \mathrm{~d}^{-1}$.

The calculated values of bacterioplankton respiration in waters of the Equatorial Divergence and of the Trade Wind Current in the layers of microbial maxima attained 10 to $20 \mu \mathrm{g} \mathrm{O}_{2} \mathrm{l}^{-1} \mathrm{~d}^{-1}$. Average respiration rates within the euphotic zone varied from 3 to $10 \mu \mathrm{g}$ $\mathrm{O}_{2} \mathrm{l}^{-1} \mathrm{~d}^{-1}$.

At several stations in regions of the trenches Vema, Argo, and Triple Point the vertical distribution of bacterioplankton numbers and biomasses was examined down to depths of ca $1000 \mathrm{~m}$. (Tables $3 \& 4$; Fig. 7). In Trenches below $200 \mathrm{~m}$ these values attained a minimum of 2 to $10 \times 10^{3} \mathrm{ml}^{-1}$ and 0.3 to $2 \mathrm{mg} \mathrm{m}^{-3}$, respectively. At 500 to $600 \mathrm{~m}$ depths near the upper boundary of the Intermedial Antarctic Waters the deep maximum of bacterioplankton was recorded. In the convergence area of Triple Point this maximum was observed at 550 to $600 \mathrm{~m}$ depth. Even below $700 \mathrm{~m}$ the total number of bacteria was comparatively high: 6 to $15 \times 10^{3} \mathrm{ml}^{-1}$, which is 2 to 3 times more than at same depths in the areas of the Tropical Oligotrophic Waters in the Pacific Ocean (Sorokin 1971). Microbial production at the deep bacterioplankton maximum was 0.7 to 
Table 3. Bacterioplankton and its activity on a vertical profile in areas of the Trench Argo (St. 2155) and the Triple Point (St. 2244). D: depth $(\mathrm{m}) ; \mathrm{N}$ : total number of bacteria $\left(10^{3} \mathrm{ml}^{-1}\right)$; B: biomass; P: production of bacteria per day (mg $\left.\mathrm{m}^{-3}\right)$; $\mathrm{M}$ : microbial respiration $\left(\mathrm{\mu gO}_{2} \mathrm{l}^{-1} \mathrm{~d}^{-1}\right)$; PP: potential microbial production ( $\mathrm{mg} \mathrm{m} \mathrm{m}^{-3}$ ); A: activity of heterotrophic bacteria (relative values)

\begin{tabular}{|c|c|c|c|c|c|c|c|c|}
\hline Location & D & $N$ & B & $\mathrm{P}$ & M & $\mathrm{PP}$ & A & $\begin{array}{c}\text { Number of } \\
\text { olive cells } \\
\left(10^{3} \mathrm{l}^{-1}\right)\end{array}$ \\
\hline \multirow[t]{10}{*}{ Argo } & 0 & 80 & 16.0 & 10.6 & 5.9 & 312 & 100 & 0 \\
\hline & 108 & 106 & 22.0 & 12.6 & 7.1 & 277 & 75 & 25 \\
\hline & 250 & 34 & 5.2 & 0.7 & 0.4 & 124 & 3 & 270 \\
\hline & 350 & 10 & 2.2 & 0.5 & 0.3 & 92 & 2 & 41 \\
\hline & 450 & 6 & 0.9 & 1.8 & 1.0 & 107 & 1 & 84 \\
\hline & 500 & 56 & 11.2 & 1.4 & 0.8 & 135 & 3 & 22 \\
\hline & 550 & 62 & 12.6 & 2.9 & 1.6 & 122 & 13 & 45 \\
\hline & 600 & 19 & 2.7 & 0.4 & 0.22 & 77 & 16 & 8 \\
\hline & 700 & 14 & 1.7 & 0.3 & 0.17 & 234 & 8 & 4 \\
\hline & 1000 & 13 & 1.6 & 0.1 & 0.06 & 279 & 5 & 0 \\
\hline \multirow[t]{10}{*}{ Triple Point } & 0 & 75 & 15.0 & 16.20 & 9.16 & 173 & 100 & 0 \\
\hline & 120 & 36 & 7.2 & 1.70 & 0.96 & 157 & 24 & 15 \\
\hline & 200 & 19 & 2.2 & 0.53 & 0.31 & 112 & 18 & 63 \\
\hline & 300 & 12 & 1.8 & 0.34 & 0.19 & 151 & 5 & 67 \\
\hline & 400 & 31 & 3.7 & 0.22 & 0.12 & 66 & 2 & 22 \\
\hline & 500 & 53 & 8.4 & 1.17 & 0.66 & 81 & 3 & 56 \\
\hline & 550 & 81 & 12.0 & 0.72 & 0.40 & 95 & 29 & 120 \\
\hline & 600 & 33 & 4.9 & 0.27 & 0.15 & 79 & 30 & 670 \\
\hline & 700 & 24 & 2.8 & 0.10 & 0.06 & 64 & 4 & 73 \\
\hline & 900 & 12 & 1.4 & 0.10 & 0.06 & 140 & 1 & 23 \\
\hline
\end{tabular}

Table 4. Bacterioplankton and its productivity on a vertical profile at Station 2115, Vima Trench. For explanation see Table 3

\begin{tabular}{|rrrccrc|}
\hline $\begin{array}{c}\text { Depth } \\
(\mathrm{m})\end{array}$ & $\mathrm{N}$ & $\mathrm{B}$ & $\mathrm{P}$ & $\mathrm{M}$ & $\mathrm{PP}$ & $\begin{array}{c}\text { Number of } \\
\text { olive cells } \\
\left(10^{3} \mathrm{l}^{-1}\right)\end{array}$ \\
\hline & & & & & & 0 \\
75 & 116 & 16.2 & 22.60 & 12.70 & 264 & 0 \\
100 & 49 & 6.0 & 19.40 & 11.00 & 310 & 0 \\
150 & 68 & 10.2 & 0.61 & 0.35 & 103 & 11 \\
300 & 22 & 4.4 & 0.34 & 0.19 & 51 & 65 \\
400 & 4 & 0.6 & 0.27 & 0.09 & 69 & 240 \\
500 & 13 & 1.6 & 0.96 & 0.54 & 130 & 140 \\
2000 & 6 & 1.0 & 0.10 & 0.06 & 170 & 380 \\
4200 & 14 & 1.4 & 0.15 & 0.08 & 55 & 28 \\
4950 & 12 & 2.4 & 0.10 & 0.06 & 42 & 45 \\
5200 & 10 & 1.0 & 0.10 & 0.06 & 71 & 118 \\
& & & & & & \\
\hline
\end{tabular}

$3 \mathrm{mg} \mathrm{m}^{-3} \mathrm{~d}^{-1}$; microbial respiration, 0.4 to $1.7 \mu \mathrm{g} \mathrm{O}_{2} \mathrm{l}^{-1}$ $\mathrm{d}^{-1}$. Outside this maximum in the 300 to $500 \mathrm{~m}$ layer microbial production was less than $0.7 \mathrm{mg} \mathrm{m}^{-3}$. Below $600 \mathrm{~m}$, microbial production was less than $0.2 \mathrm{mg} \mathrm{m}^{-3}$, and respiration less than $0.1 \mu \mathrm{g} \mathrm{O}_{2} \mathrm{l}^{-1}$, or 10 to $30 \mu \mathrm{g}$ $\mathrm{O}_{2} \mathrm{l}^{-1} \mathrm{yr}^{-1}$.

The relative activity of natural bacterioplankton, as determined by using labelled organic matter (Tables 3 \& 4; Fig. 7), decreased below $200 \mathrm{~m}$ by more than 1 order of magnitude. However, in the layer of the deep bacterioplankton maximum it increased several times.

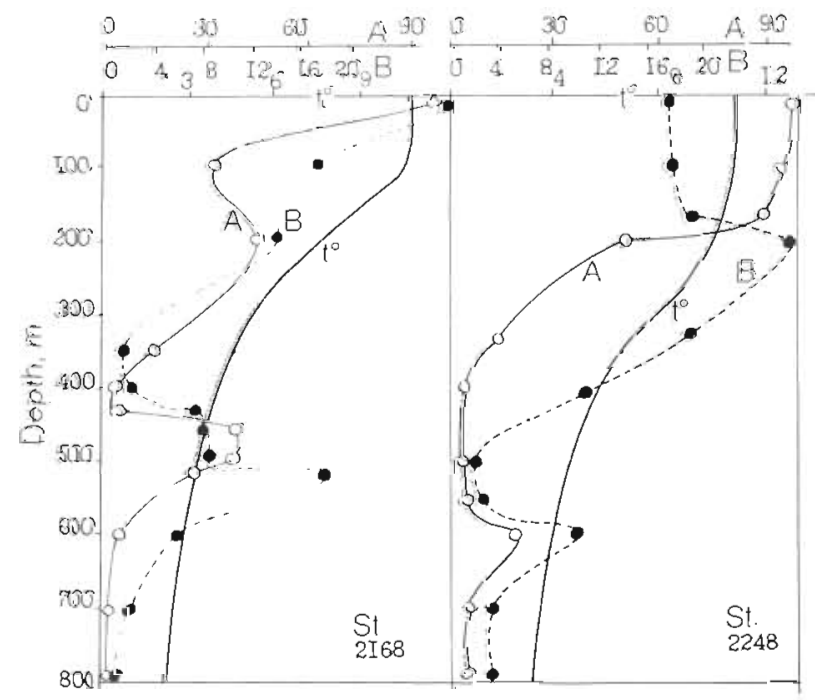

Fig. 7. Distribution of temperature $\left(\mathrm{t}^{\circ}\right)$, bacterioplankton biomass $\left(\mathrm{B}, \mathrm{mg} \mathrm{m} \mathrm{m}^{-3}\right.$ ) and of its relative activity $(\mathrm{A}, \%)$ at Station 2168 (Argo trench, Trade Wind Current), and at Station 2248 (South Tropical Convergence)

In the deep-water samples we studied the quantity of the so-called 'olive cells' described by Hentschel (1936, see 'Methods'). Counts on membrane filters (Tables 3 \& 4) showed that the maxima of their num-

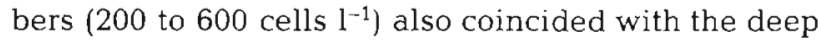
microbial maximum at 500 to $600 \mathrm{~m}$ depth. But sometimes significant amounts (up to $270 \times 10^{3}$ cells $1^{-1}$ ) 
were found at depths of 200 to $250 \mathrm{~m}$. Their sizes ranged from 2 to $5 \mu \mathrm{m}$. The biomass of these cells examined at the filters was usually small $(0.3$ to $1 \mathrm{mg}$ $\mathrm{m}^{-3}$ ). At Station 2255 the numbers of olive cells were counted in the chamber in same way as those of the zooflagellates. The number obtained ranged up to $100 \times 10^{3} \mathrm{l}^{-1}$ (in the 300 to $400 \mathrm{~m}$ layer).

Microscopic examination of deep-water samples in the box chamber (Fig. 2) immediately after arrival of the water bottle revealed greenish, evenly coloured small microflagellates ( 3 to $6 \mu \mathrm{m}$ ). Continous observation of the individually moving cells showed that during the gradual increase of water temperature in the chamber the microflagellate cells ceased to move, lost their flagellae and formed cysts not distinguishable from olive or green cells, indicating that they could be actually the cysts of microflagellates.

\section{Zooflagellates}

Observations on species composition of populations of free-living planktonic zooflagellates in the central parts of the Indian Ocean were made by microscopic examination of the freshly taken water samples in the box chamber. The bulk of their populations was presented here by the naked zooflagellates from the orders Kinetoplastida and Protomonadida. Mass species were Bodo parvus Grossman 1914, Bodo saltans Ehrenberg 1938, Rhynchomonas sp., Oicomonas sp., and Pleurosiga sp. Zooflagellates with lorica (Choanoflagellida, Bicosoecida) were rare and composed a minor part of the numbers and biomasses of zooflagellates in the tropical waters investigated.

Larger numbers of planktonic zooflagellates were found to be free-swimming. But often the specimens (mostly of the order Protomonadida) were also observed attached to detrital particles, 5 to $50 \mu \mathrm{m}$ in size.
If the particle was small the attached flagellate moved slowly; if it was large the zooflagellate cell usually penetrated into the mass of the particle. In waters of the Trade Wind Current, cells of zooflagellates (mostly Promonadida) were often attached to living as well as to dead diatoms (Chaetoceros sp. and Rhyzosolenia sp.). To 1 cell of Chaetoceros were sometimes up to 50 cells of zooflagellates attached, all of them to its chaeta. Zooflagellates were also attached to abandoned chitin skeletons of crustaceans. Observations on decaying copepods showed that zooflagellates actively participated in this process besides bacteria and small ciliates. They accumulated outside and within the decaying crustacean bodies. Their generation time was 20 to $60 \mathrm{~min}$. These observations suggest that the zooflagellates not only inhabit the empty chitin skeletons of dead crustaceans but also participate in the decomposition of dead animals.

Typical vertical distribution patterns of zooflagellates are shown in Fig. $8 \& 9$ and in Table 5. They depended upon the character of stratification in the same way as phytoplankton and bacteria do. In waters of the Equatorial Divergence and of the Trade Wind Currents $\left(0\right.$ to $\left.12^{\circ} \mathrm{S}\right)$, where the thermocline boundary was shallow (50 to $60 \mathrm{~m}$ ), 2 or sometimes 3 maxima were observed: near the surface, at 10 to $20 \mathrm{~m}$ depth, and at the upper part of the thermocline. Attached zooflagellates were more numerous at the surface and at the thermocline. At the southern boundary of the Trade Wind Current and in the southern Tropical Convergence, where the depth of the mixed layer approached the lower boundary of the euphotic zone, the main maximum of zooflagellates was usually situated near the surface, more rarely at the boundary of the thermocline.

Total numbers and biomasses of zooflagellates in the maxima layers ranged from 160 to $930 \times 10^{3} \mathrm{l}^{-1}$ and 10

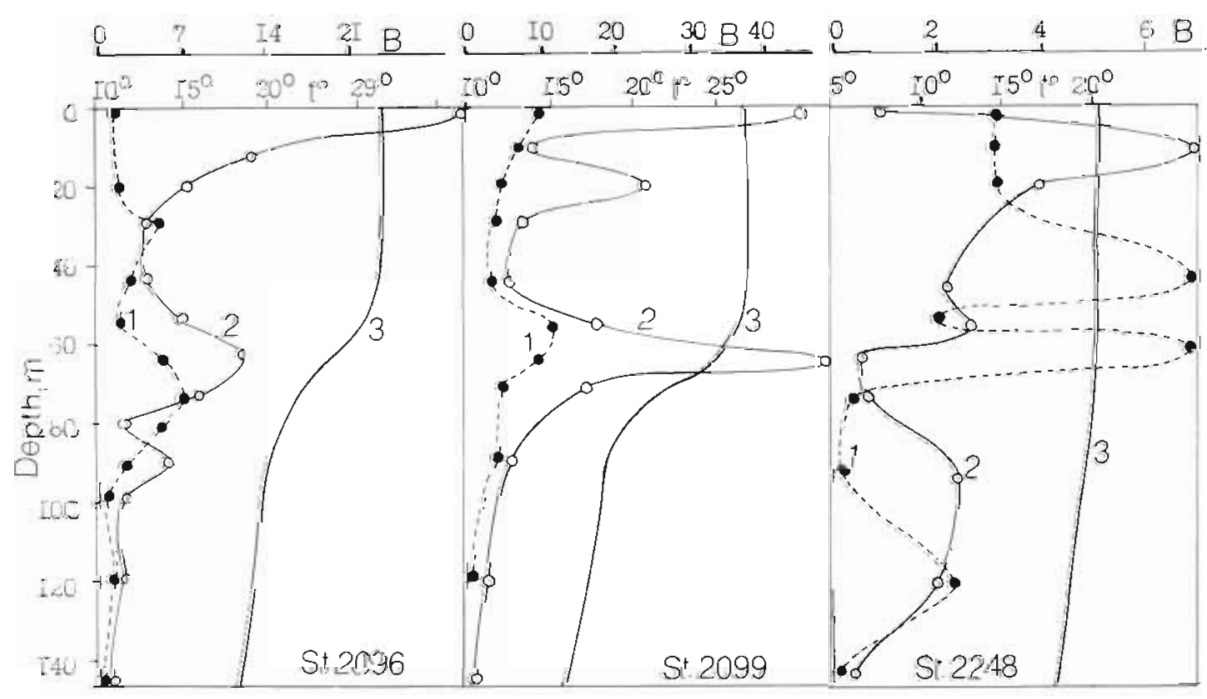

Fig. 8. Vertical distribution of the biomass of planktonic protozoans $\left(B, \mathrm{mg} \mathrm{m}^{-3}\right)$ in Equatorial Divergence (St. 2096), Trade Wind Current (St. 2099), and South Tropical Convergence (St. 2248). 1: ciliates; 2 : zooflagellates; 3 : water temperature $\left(t^{\circ} \mathrm{C}\right)$ 


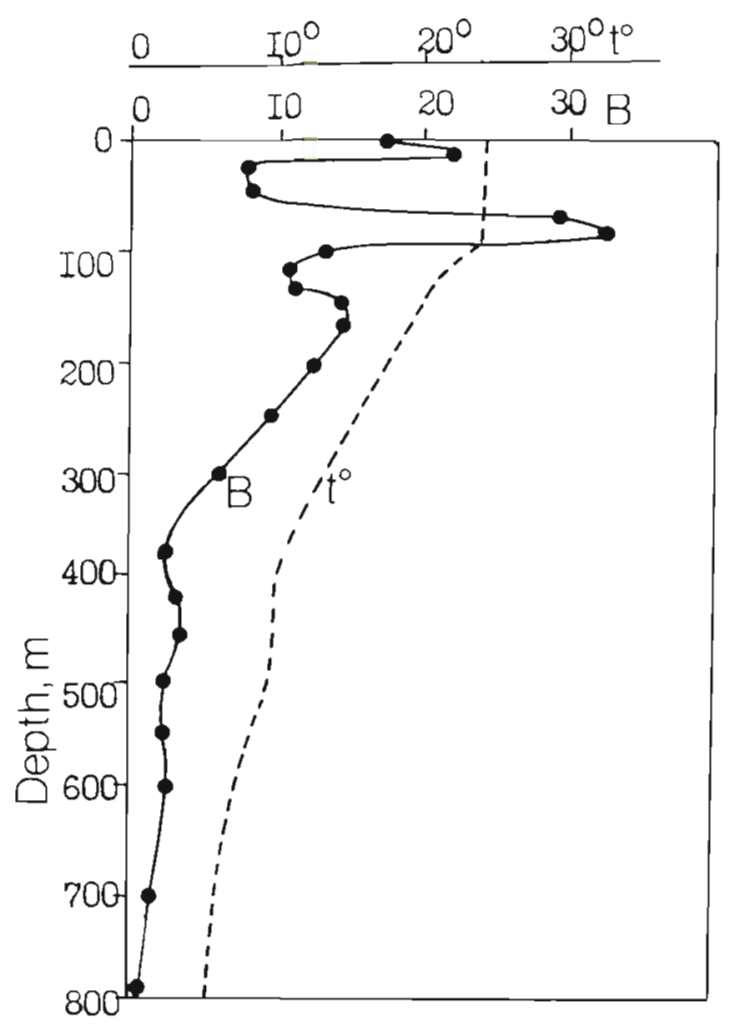

Fig. 9. Distribution of the biomass of zooflagellates ( $B$, mg $\mathrm{m}^{-3}$ ) over a vertical profile at Station 2168 . $\mathrm{t}^{\circ}$ : water temperature.

to $65 \mathrm{mg} \mathrm{m} \mathrm{m}^{-3}$, respectively. Average numbers within the euphotic zone outside of the layers maximum were between 30 and $200 \times 10^{3} \mathrm{l}^{-1}$, and biomasses between 3 and $20 \mathrm{mg} \mathrm{m}^{-3}$.
Table 5. Vertical distribution of numbers (N) and biomasses (B) of zooflagellates at Station 2155

\begin{tabular}{|cccc|}
\hline $\begin{array}{c}\text { Depth } \\
(\mathrm{m})\end{array}$ & $\begin{array}{c}\text { Water tem- } \\
\text { perature }\left({ }^{\circ} \mathrm{C}\right)\end{array}$ & $\begin{array}{c}\mathrm{N} \\
\left(10^{3} \mathrm{l}^{-1}\right)\end{array}$ & $\begin{array}{c}\mathrm{B} \\
\left(\mathrm{mg} \mathrm{m}^{-3}\right)\end{array}$ \\
\hline 0 & 21.8 & 156 & 6.9 \\
20 & 21.8 & 208 & 9.4 \\
50 & 21.8 & 26 & 0.9 \\
70 & 21.8 & 156 & 2.2 \\
100 & 21.2 & 26 & 0.9 \\
150 & 20.2 & 104 & 6.8 \\
300 & 13.5 & 260 & 11.3 \\
500 & 8.5 & 104 & 3.5 \\
600 & 6.7 & 104 & 3.5 \\
1000 & - & 26 & 2.7 \\
2000 & - & 13 & 0.8 \\
& & & \\
\hline
\end{tabular}

The integral biomass in the water column of the euphotic zone remained within the limits 0.5 to $2.8 \mathrm{~g}$ $\mathrm{m}^{-2}$ (Table 6). Among the areas of the central Indian Ocean investigated, zooflagellates were most abundant in the waters of the Trade Wind Current (average for all stations: $1.2 \mathrm{~g} \mathrm{~m}^{-2}$ ).

Zooflagellates were also found in deep-water samples down to $2000 \mathrm{~m}$ depth (Fig. 9; Table 5). In the layer of the deep bacterioplankton maximum (400 to $600 \mathrm{~m}$; Tables 3 \& 4) zooflagellates were quite numerous (up to $10^{5}$ cells $\mathrm{l}^{-1}$ ). At those depths their biomass attained the same level as that ' of the bacterioplankton (Table 5). In addition to the zooflagellates other heterotrophic microplankters were present in deep-

Table 6. Number (N) and biomass (B) of protozooplankton in layers of maxima (max) and averages (ave) within the euphotic zone as well as integral values under $1 \mathrm{~m}^{2}$ water column in 0 to $150 \mathrm{~m}$ depth

\begin{tabular}{|c|c|c|c|c|c|c|c|c|c|c|}
\hline \multirow{3}{*}{ Station } & \multicolumn{5}{|c|}{ Zooflagellates } & \multicolumn{5}{|c|}{ Ciliates } \\
\hline & \multirow{2}{*}{$\begin{array}{l}\text { Depths of } \\
\text { maximum } \\
\text { numbers } \\
\text { (m) }\end{array}$} & \multirow{2}{*}{$\begin{array}{c}N \\
(\max ) \\
10^{5} 1^{-1}\end{array}$} & \multicolumn{2}{|c|}{$\mathrm{B}\left(\mathrm{mg} \mathrm{m}^{-3}\right)$} & \multirow{2}{*}{$\begin{array}{c}\mathrm{B} \\
\left(\mathrm{mg} \mathrm{m}^{-2}\right)\end{array}$} & \multirow{2}{*}{$\begin{array}{l}\text { Depths } \\
\text { maximum } \\
\text { numbers } \\
\text { (m) }\end{array}$} & \multirow{2}{*}{$\begin{array}{c}N \\
(\max ) \\
10^{3} 1^{-1}\end{array}$} & \multicolumn{2}{|c|}{$\mathrm{B}\left(\mathrm{mg} \mathrm{m}^{-3}\right)$} & \multirow{2}{*}{$\begin{array}{c}\mathrm{B} \\
\left(\mathrm{mg} \mathrm{m} \mathrm{m}^{-2}\right)\end{array}$} \\
\hline & & & $\max$ & ave & & & & $\max$ & ave & \\
\hline 2096 & 0 & 3.90 & 31.2 & 5.6 & 847 & 70 & 0.2 & 8.2 & 1.9 & 289 \\
\hline 2097 & 70 & 2.60 & 14.6 & 4.4 & 657 & 65 & 0.3 & 9.6 & 1.9 & 285 \\
\hline 2098 & 45 & 9.28 & 65.5 & 10.1 & 1514 & 50 & 0.3 & 10.8 & 1.8 & 270 \\
\hline 2099 & 20 & 3.64 & 25.9 & 8.5 & 1275 & 60 & 0.2 & 9.9 & 3.7 & 556 \\
\hline 2100 & 80 & 2.60 & 18.9 & 3.1 & 464 & 60 & 0.1 & 5.1 & 0.5 & 69 \\
\hline 2101 & 20 & 2.08 & 15.7 & 4.6 & 685 & 120 & 0.04 & 2.1 & 0.22 & 34 \\
\hline 2102 & 0 & 2.08 & 13.9 & 6.1 & 915 & 160 & 0.010 & 0.2 & 0.09 & 14 \\
\hline 2103 & 0 & 4.68 & 21.7 & 13.9 & 2079 & 100 & 0.09 & 4.3 & 0.85 & 128 \\
\hline 2107 & 0 & 15.6 & 10.4 & 3.1 & 467 & 80 & 0.08 & 4.0 & 0.3 & 48 \\
\hline 2108 & 0 & 3.12 & 15.7 & 5.4 & 813 & 80 & 0.3 & 11.0 & 1.7 & 259 \\
\hline 2109 & 50 & 6.76 & 44.8 & 19.1 & 2871 & 0 & 0.2 & 10.0 & 2.0 & 300 \\
\hline 2168 & 90 & 4.16 & 33.4 & 12.4 & 1861 & 100 & 0.09 & 4.2 & 0.17 & 25 \\
\hline 2189 & 100 & 5.20 & 15.2 & 6.5 & 973 & 100 & 0.6 & 30.1 & 4.9 & 742 \\
\hline 2237 & 0 & 3.12 & 13.5 & 4.7 & 706 & 90 & 0.13 & 6.2 & 1.3 & 191 \\
\hline 2243 & 30 & 3.12 & 12.2 & 3.2 & 475 & 5 & 0.2 & 9.0 & 2 & 250 \\
\hline 2248 & 10 & 2.08 & 11.9 & 3.5 & 520 & 45 & 0.2 & 10.0 & 2 & 220 \\
\hline 2255 & 10 & 3.16 & 12.2 & 3.3 & 500 & - & - & - & - & - \\
\hline
\end{tabular}



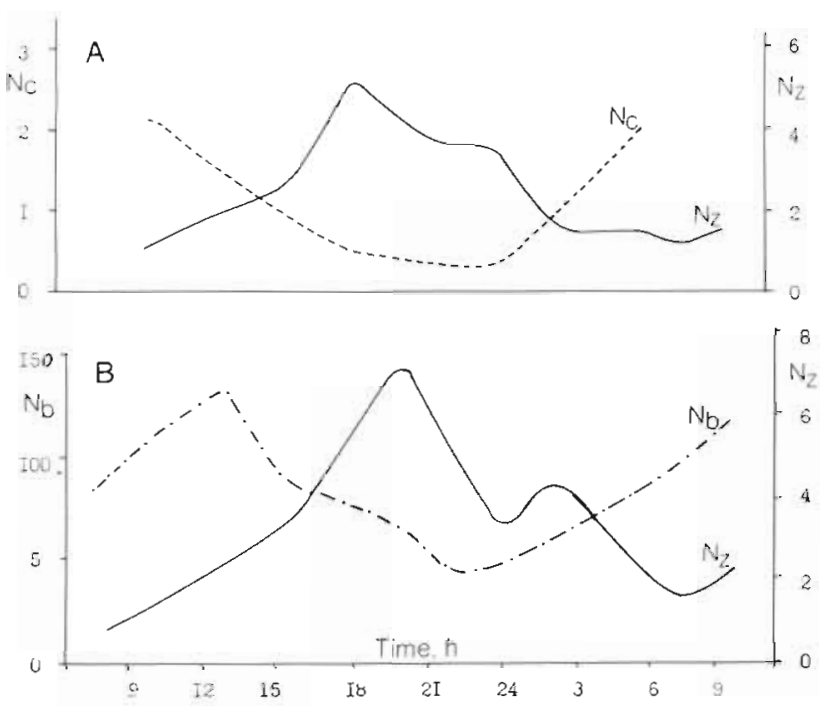

Fig. 10. Diurnal change in number of planktonic microheterotrophes in the surface water layer at Station 2109 (A) and Station 2189 (B). $N_{z}$ : number of zooflagellates $\left(10^{5} l^{-1}\right)$; $\mathrm{N}_{c}$ : number of ciliates $\left(10^{2} 1^{-1}\right) ; \mathrm{N}_{\mathrm{b}}$ : number of bacteria $\left(10^{4} \mathrm{ml}^{-1}\right)$

water samples, such as colourless dinoflagellates, small radiolarians, ciliates, and the olive cells found to be the cysts of microflagellates (see above).

Observations on diurnal changes in the vertical distributions and abundances of zooflagellates within the euphotic zone were accomplished at Station 2109. The results (Fig. 10) demonstrated significant diurnal changes. Maximum values within the $24 \mathrm{~h}$ cycle were recorded at $1800 \mathrm{~h}$ at the subsurface (10 $\mathrm{m}$ depth), and at the upper boundary of the thermocline (60 to $65 \mathrm{~m}$ ). At night the latter maximum disappeared, perhaps as a consequence of night grazing by migrating copepods. In the morning (0600 h) only the subsurface maximum was observed. In the evening the second maximum at $60 \mathrm{~m}$ depth appeared again. At Station 2189 observations on diurnal changes in the number of zooflagellates at the surface ( 1 to $3 \mathrm{~m}$ depth) also revealed significant diurnal variations. Two minima were recorded: at 0600 to $0900 \mathrm{~h}$ in the morning and at about $2400 \mathrm{~h}$ at night. During the minimum the numbers were 3 to 6 times less then those during the maximum (Fig. 10). The curves of diurnal zooflagellate changes were reciprocal to those of the ciliates; this suggests prey-predator relations between these 2 groups of planktonic protozoans.

\section{Ciliates}

Populations of planktonic ciliates in the region investigated were presented by 31 species with small variations along the meridional cross-section. Naked ciliates of the genus Strombidim dominated at all stations. They composed the main part of the total numbers and biomasses of ciliates within the euphotic zone. By number and biomass the tintinnids comprised a minor part of the ciliate population. They were represented by 23 species. The most common species were: Strombidium sp., Tiarina fusus, Tontonia gracilissima, Tintinnus tenue, T. perminutus, Rhabdonellopsis apophysata, Vorticella furnicata. Vorticella cells were attached to diatoms (usually to the chaetae of Chaetoceros species). The tintinnid $T$. perminutus was often found also attached to living Chaetoceros sp. Perhaps this points to a symbiosis.

Maximum numbers and biomasses of planktonic ciliates on the vertical profile were recorded in waters of the Equatorial Divergence and of the Trade Wind Current where the boundary of the thermocline was high (Table 6). In the maximum layer at this boundary the numbers of ciliates ranged from 0.2 to $0.6 \times 10^{-3} \mathrm{l}^{-1}$ and their biomasses from 10 to $30 \mathrm{mg}$ $\mathrm{m}^{-3}$. In the oligotrophic waters of the Southern Tropical Convergence numbers and biomasses of ciliates decreased. The biomasses of ciliates in the layer 0 to $150 \mathrm{~m}$ in more productive areas between 0 and $12^{\circ} \mathrm{S}$ was 270 to $560 \mathrm{mg} \mathrm{m}^{-2}$; in the convergence area, 14 to $35 \mathrm{mg} \mathrm{m}^{-2}$.

The vertical distribution of ciliates (Fig. 8) in waters with a high thermocline revealed 2 peculiar maxima, one at 10 to $20 \mathrm{~m}$, the other at the boundary of the thermocline. In areas of convergence with a deep thermocline the deep maximum was often absent. The population of ciliates aggregated there in the upper water layers (Fig. 8). Below $200 \mathrm{~m}$ depth the ciliates were rare.

\section{Radiolarians and nauplii}

Their counts in samples concentrated on Nuclepore filters are listed in Table 7. Radiolarians (including Acantharia) were found in samples of all stations. At stations in the Equatorial and Trade Wind Currents their average numbers ranged from 1 to $201^{-1}$; in areas of convergence, from 0.1 to $0.3 \mathrm{l}^{-1}$. Maxima of their numbers were usually found near the surface or at the upper boundary of thermocline. For example, at Station 2097 at $60 \mathrm{~m}$ depth the value was $50 \mathrm{l}^{-1}$. Biomass of radiolarians in the euphotic zone (0 to $150 \mathrm{~m})$ was, in more productive waters of the divergence (St. 2097 to 2098), relatively high (137 to $\left.360 \mathrm{mg} \mathrm{m}^{-2}\right)$. At most other stations outside the convergence the biomass ranged from 10 to $50 \mathrm{mg} \mathrm{m}^{-2}$, and in the convergence area it was only $4 \mathrm{mg} \mathrm{m}^{-2}$. Nauplii biomass in the water column remained within the same ranges as that of radiolarians. The biomass of radiolarians at different 
Table 7. Numbers (N) and biomasses (B) of components of microzooplankton in layers of maxima (max) and their integral biomasses under $1 \mathrm{~m}^{2}$ in 0 to $150 \mathrm{~m}$ depth

\begin{tabular}{|c|c|c|c|c|c|c|}
\hline \multirow[t]{3}{*}{ Station } & \multicolumn{3}{|c|}{ Radiolarians } & \multicolumn{3}{|c|}{ Nauplii } \\
\hline & \multicolumn{2}{|c|}{$\max$} & \multirow{2}{*}{$\begin{array}{c}B \\
\left(m g m^{-2}\right)\end{array}$} & \multicolumn{2}{|c|}{$\max$} & \multirow{2}{*}{$\begin{array}{c}B \\
\left(\mathrm{mg} \mathrm{m}^{-2}\right)\end{array}$} \\
\hline & $\begin{array}{c}N \\
\left(1^{-1}\right)\end{array}$ & $\begin{array}{c}\mathrm{B} \\
\left(\mathrm{mg} \mathrm{m}^{-3}\right)\end{array}$ & & $\begin{array}{c}N \\
\left(1^{-1}\right)\end{array}$ & $\begin{array}{c}\mathrm{B} \\
\left(\mathrm{mg} \mathrm{m}^{-3}\right)\end{array}$ & \\
\hline 2096 & 8 & 32 & 320 & 10 & 0.8 & 41 \\
\hline 2097 & 50 & 200 & 405 & 100 & 8 & 305 \\
\hline 2098 & 10 & 40 & 137 & 10 & 0.8 & 54 \\
\hline 2099 & 5 & 20 & 31 & 4 & 0.3 & 32 \\
\hline 2100 & 5 & 2 & 10 & 40 & 3.2 & 38 \\
\hline 2101 & 2 & 8 & 10 & 4 & 0.3 & 39 \\
\hline 2102 & 1 & 4 & 18 & 4 & 0.3 & 36 \\
\hline 2103 & 1 & 4 & 4 & 2 & 0.2 & 11 \\
\hline 2107 & 1 & 4 & 4 & 5 & 0.4 & 24 \\
\hline 2108 & 6 & 24 & 54 & 10 & 0.8 & 46 \\
\hline 2109 & 7 & 28 & 40 & 6 & 0.5 & 30 \\
\hline 2168 & 3 & 12 & 28 & 3 & 0.2 & 18 \\
\hline 2185 & 1 & 4 & 38 & 2 & 0.2 & 20 \\
\hline 2236 & 1 & 4 & 14 & 3 & 0.2 & 26 \\
\hline
\end{tabular}

stations comprised between 5 to $30 \%$ of the total microzooplankton biomass (ciliates and zooflagellates). The biomass of nauplii comprised 10 to $30 \%$ of the total microzooplankton biomass.

\section{DISCUSSION}

This study of the vertical distributions of microplankton supports the general scheme established earlier for stratified tropical oceanic waters (Sorokin 1971, 1973,1981 ). The main microplankton maximum occurs at the upper thermocline boundary, where the bacterioplankton, phytoplankton and protozoans usually attain maxima (Fig. 3, 4 \& 8), and where the mezozooplankton aggregates (Sorokin 1973) which utilizes this microplankton stock. The second maximum within the water column occurs at the upper boundary of the Intermedial Antarctic Waters (500 to $600 \mathrm{~m}$ ), where maxima of bacterioplankton and phytoplankton prevail. This regularity in the vertical distribution of microplankton occurs in areas where the thermocline boundary lies at $100 \mathrm{~m}$ depth. In convergence areas where the boundary is deeper, maximal microplankton concentrations are usually observed at the surface (Fig. 8). These data prove that sampling depths must be selected at each station after previous vertical recording of some of the indicators of the vertical watercolumn structure or of the plankton community itself, such as temperature, turbidity, bioluminescence or chlorophyll (Sorokin 1971, Gitelson et al. 1971).

The higher values of primary production $(0.4$ to $1.4 \mathrm{~g}$ $\mathrm{C} \mathrm{m}^{-2} \mathrm{~d}^{-1}$ ) were found in areas of intensive water-mass dynamics: the Moonson and Trade Wind Currents and the Equatorial Divergence. As indicator of the intensity of these dynamics the phosphate concentrations at $100 \mathrm{~m}$ depth may be used (Table 8). The upper boundary of an efficient phosphorus flow from deeper layers was situated, in these areas, within the euphotic zone. Here, diatoms were predominant. Their highest abundancies were observed in the area of Carlsberg Ridge (St. 2108, 2109, 2168).

The comparison of our data on primary production with corresponding data reviewed by Koblentz Mishke et al. (1970) shows that ours are 2 to 3 times higher. The cause for this difference surely lies in the underestimation of photosynthesis rates by previous investigators, who used an old version of the ${ }^{14} \mathrm{C}$ method. Workers who used this version did not account for the loss of about half of the assimilated ${ }^{14} \mathrm{C}$ during filtration, missed a large portion of the phytoplankton population by sampling from standard or light-penetration-dependent depths, lost a lot of fixed ${ }^{14} \mathrm{C}$ due to storage of dry filters, etc. (Sorokin 1971, De Vooys 1979).

A direct correlation between primary production and bacterioplankton production was in fact absent. In the areas of convergence the former was up to 5 to 10 times lower than in areas of the main currents but there the microbial biomass and production were only 1.5 to 2 times lower. At Station 2243 they were at the same level as in the areas of a high primary production. These observation prove that in tropical waters phytoplankton production is not the single source of nutrition for bacterioplankton (Sorokin 1978). An additional stock of organic matter could be brought here from the areas of temperate and cold waters by surface currents and by meridional advection of Intermedial Antartic Waters.

The maxima of bacterioplankton and, especially, of microflagellates at the upper boundary of the Intermedial Antartic Waters (Tables 3, 4 \& 5) probably provide a most important nutrient source for mesopelagic filterfeeding zooplankters. In accordance with data on the potential production of bacteria (Tables $3 \& 4$ ) the Intermedial Antarctic as well as the Deep Oceanic Waters in tropical latitudes contain a significant stock of the labile organic matter accessible for bacterioplankton. The single source of its origin could be the primary production in high-latitude productive surface waters, where the formation of the intermedial and deep-water masses proceeds.

Measurements of biomass, production and metabolism of the main microplankton components are summarized in Table 8, where integrated data are given per $1 \mathrm{~m}^{2}$ in the euphotic zone (0 to $150 \mathrm{~m}$ ). Data on mesozooplankton are given after Moiseev (1969) and Vinogradov (1977). Using original and literature data on average $\mathrm{P} / \mathrm{B}$ coefficients, and $\mathrm{K}_{2}$ coefficients (caloric equivalents and assimilability), we obtained approximate calculations of the respiration of micro- and 
Table 8. Integral parameters of biomass, production and metabolism of the main components of plankton in the upper $150 \mathrm{~m}$ layer. $\mathrm{B}$ : biomass $\left(\mathrm{g} \mathrm{m}^{-2}\right)$, wet weight; $P$ : production $\mathrm{d}^{-1}$ (same units); $\mathrm{M}$ : respiration $\left(\mathrm{kcal} \mathrm{m}^{-2} \mathrm{~d}^{-1}\right)$

\begin{tabular}{|c|c|c|c|c|c|c|c|c|c|c|c|c|c|c|}
\hline \multirow[t]{2}{*}{ Area } & \multirow{2}{*}{$\begin{array}{l}\text { Sta- } \\
\text { tion }\end{array}$} & \multirow[b]{2}{*}{$\begin{array}{l}\text { Depths } \\
\text { of upper } \\
\text { boun- } \\
\text { dary } \\
\text { of ther- } \\
\text { mocline } \\
\text { (m) }\end{array}$} & \multirow[b]{2}{*}{$\begin{array}{c}\mathrm{PO}_{4}-\mathrm{P} \text { at } \\
\text { depth } \\
100 \mathrm{~m} \\
(\mathrm{\mu g} \text { at } \\
\left.\mathrm{I}^{-1}\right)\end{array}$} & \multirow[b]{2}{*}{$\begin{array}{c}\text { Primary } \\
\text { phyto- } \\
\text { plankton } \\
\text { produc- } \\
\text { tion } \\
\left(\mathrm{gC} \mathrm{m}^{-2} \mathrm{~d}^{-1}\right) \\
\left(\mathrm{P}_{\mathrm{p}}\right)\end{array}$} & \multicolumn{4}{|c|}{ Bacterioplankton } & \multicolumn{4}{|c|}{ Zooplankton } & \multirow[b]{2}{*}{$\begin{array}{c}\text { Total } \\
\text { hetero- } \\
\text { trophic } \\
\text { respl- } \\
\text { ration } \\
\left(\mathrm{M}_{\mathrm{t}}\right)\left(\mathrm{M}_{1}+\right. \\
\left.\mathrm{M}_{2}+\mathrm{M}_{3}\right)\end{array}$} & \multirow[t]{2}{*}{$\mathrm{P}_{\mathrm{p}} / \mathrm{M}_{\mathrm{t}}$} \\
\hline & & & & & B & $\mathrm{P}$ & $\mathrm{P} / \mathrm{B}$ & $M_{1}$ & $\begin{array}{l}\text { Micr } \\
\text { plar } \\
\text { B }\end{array}$ & $\begin{array}{l}\text { zoo- } \\
\text { kton } \\
\mathrm{M}_{2}\end{array}$ & $\begin{array}{l}\mathrm{Me} \\
\text { pla } \\
\text { B }\end{array}$ & $\begin{array}{l}\text { zoo- } \\
\text { kton } \\
M_{3}\end{array}$ & & \\
\hline Moonson & 2096 & 48 & $1-1.5$ & 0.84 & 1.30 & 0.87 & 0.70 & 1.68 & 1.21 & 0.63 & 6 & 0.8 & 3.11 & 2.5 \\
\hline \multirow{2}{*}{ Current } & 2097 & 50 & $1-1.5$ & 0.40 & 1.03 & 0.77 & 0.74 & 1.49 & 1.59 & 0.83 & 6 & 0.8 & 3.12 & 1.2 \\
\hline & 2098 & 55 & $1-1.5$ & 0.20 & 3.87 & 1.65 & 0.43 & 3.19 & 1.98 & 1.02 & 7 & 0.93 & 5.14 & 0.4 \\
\hline $\begin{array}{l}\text { Equatorial } \\
\text { Divergence }\end{array}$ & 2099 & 58 & 1.0 & 0.97 & 2.29 & 0.88 & 0.39 & 1.71 & 1.89 & 0.98 & 7 & 0.93 & 3.62 & 2.4 \\
\hline South & 2100 & 77 & $0.5-1$ & 0.49 & 2.23 & 1.12 & 0.50 & 2.15 & 0.58 & 0.30 & 7 & 0.93 & 3,38 & 1.3 \\
\hline Trade & 2101 & 110 & $0.2-0.5$ & 0.26 & 2.31 & 1.26 & 0.54 & 2.43 & 0.77 & 0.40 & 5 & 0.66 & 3.49 & 0.7 \\
\hline Wind & 2102 & 115 & 0.2 & 0.44 & 3.62 & 1.42 & 0.39 & 2.74 & 0.98 & 0.51 & 5 & 0.66 & 3.91 & 1.0 \\
\hline \multirow[t]{5}{*}{ Current } & 2107 & 80 & $0.2-0.5$ & 0.19 & 2.40 & 0.97 & 0.40 & 1.87 & 0.54 & 0.29 & 3 & 0.40 & 2.59 & 0.7 \\
\hline & 2108 & 70 & $0.5-1$ & 1.42 & 2.52 & 1.17 & 0.46 & 2.25 & 1.17 & 0.61 & 15 & 2.00 & 4.86 & 2.7 \\
\hline & 2109 & 65 & $0.5-1$ & 1.15 & 5.50 & 1.41 & 0.26 & 2.73 & 2.87 & 1.49 & 15 & 2.00 & 6.22 & 2.3 \\
\hline & 2168 & 90 & $0.2-0.5$ & 0.41 & 2.19 & 1.03 & 0.43 & 1.99 & 1.93 & 1.00 & 8 & 1.06 & 4.05 & 0.9 \\
\hline & 2189 & 115 & $0.2-0.5$ & 0.52 & 1.75 & 0.56 & 0.32 & 1.08 & 1.77 & 0.92 & 4 & 0.53 & 2.53 & 1.9 \\
\hline South & 2103 & 130 & 0.2 & 0.18 & 1.68 & 0.74 & 0.44 & 1.44 & 2.19 & 1.13 & 2 & 0.27 & 2.84 & 0.6 \\
\hline Tropical & 2237 & 130 & 0.2 & 0.14 & 2.48 & 0.58 & 0.23 & 1.12 & 0.93 & 0.48 & 2 & 0.27 & 1.87 & 0.7 \\
\hline Convergence & 2248 & 130 & 0.2 & 0.23 & 1.91 & 0.88 & 0.46 & 1.70 & 0.60 & 0.31 & 2 & 0.27 & 2.28 & 0.9 \\
\hline $\begin{array}{l}\text { South Indo- } \\
\text { oceanic Current }\end{array}$ & 2243 & 90 & 0.2 & 0.90 & 2.11 & 1.47 & 0.70 & 2.84 & 0.60 & 0.31 & 3 & 0.40 & 3.55 & 2.3 \\
\hline
\end{tabular}

Table 9. Elements of the energy-balance equation showing the use of food consumed by basic components of pelagic plankton communities of the main currents of the central Indian Ocean; all data given as $\mathrm{kcal} \mathrm{m}^{-2} \mathrm{~d}^{-1}$ for 0 to $150 \mathrm{~m}$ depth

\begin{tabular}{|c|c|c|c|c|c|c|}
\hline \multirow{2}{*}{$\begin{array}{l}\text { Type of } \\
\text { water }\end{array}$} & \multirow{2}{*}{$\begin{array}{l}\text { Component of } \\
\text { community }\end{array}$} & \multirow[t]{2}{*}{ Ration } & \multirow{2}{*}{$\begin{array}{l}\text { Produc- } \\
\text { tion }\end{array}$} & \multirow{2}{*}{$\begin{array}{l}\text { Non-assi- } \\
\text { milated } \\
\text { food }\end{array}$} & \multicolumn{2}{|c|}{ Respiration } \\
\hline & & & & & kcal & $\begin{array}{l}\% \text { of } \\
\text { total }\end{array}$ \\
\hline Moonson & Phytoplankton & - & 7.64 & - & - & - \\
\hline current & Bacteria & 2.48 & 0.80 & - & 1.68 & 53 \\
\hline \multirow[t]{3}{*}{ (St. 2096) } & Microzooplankton & 1.57 & 0.44 & 0.47 & 0.63 & 21 \\
\hline & Mezozoo- $\quad$ herbivorous & 1.80 & 0.32 & 0.90 & 0.58 & 19 \\
\hline & predatory & 0.48 & 0.12 & 0.14 & 0.22 & 7 \\
\hline Trade & Phytoplankton & - & 4.40 & - & - & - \\
\hline Wind & Bacteria & 3.15 & 1.00 & - & 2.15 & 62 \\
\hline Current & Microzooplankton & 0.97 & 0.27 & 0.30 & 0.40 & 12 \\
\hline at $280^{\circ} \mathrm{E}$ & Mezozoo- herbivorous & 2.10 & 0.37 & 1.05 & 0.68 & 19 \\
\hline (St. 2100) & predatory & 0.56 & 0.14 & 0.17 & 0.25 & 7 \\
\hline Trade & Phytoplankton & - & 10.50 & - & - & - \\
\hline Wind & Bacteria & 4.00 & 1.28 & - & 2.72 & 44 \\
\hline Current & Microzooplankton & 3.50 & 1.95 & 1.05 & 1.50 & 24 \\
\hline (area of & Mezozoo- herbivorous & 4.44 & 0.78 & 2.22 & 1.44 & 23 \\
\hline $\begin{array}{l}\text { Carlsberg Ridge) } \\
\text { (St. 2109) }\end{array}$ & predatory & 1.20 & 0.30 & 0.36 & 0.56 & 9 \\
\hline South & Phytoplankton & - & 1.24 & - & - & - \\
\hline Tropical & Bacteria & 1.65 & 0.53 & - & 1.12 & 60 \\
\hline Convergence & Microzooplankton & 1.15 & 0.32 & 0.34 & 0.49 & 25 \\
\hline \multirow[t]{2}{*}{ (St. 2237) } & Mezozoo- herbivorous & 0.44 & 0.08 & 0.22 & 0.14 & 8 \\
\hline & predatory & 0.28 & 0.07 & 0.08 & 0.13 & 7 \\
\hline
\end{tabular}


mesozooplankton as well as the rates of total hetertrophic respiration, and calculated the ratios of primary production to heterotrophic respiration (heterotrophic destruction of organic matter) within the euphotic zone. This ratio is an important functional parameter of the activity of the planktonic community. The abovementioned parameters for these calculations were taken as follows: for microzooplankton; P/B coefficients per day $=0.5, \mathrm{~K}_{2}$ coefficient $=0.4$, caloric equivalent of biomass $=0.8 \mathrm{kcal} \mathrm{g}^{-1}$, assimilability $=$ 0.7 ; for mezozooplankton, $\mathrm{P} / \mathrm{B}=0.12, \mathrm{~K}_{2}=0.35$, caloric equivalent $=0.6 \mathrm{kcal} \mathrm{g}^{-1} \mathrm{~m}$, assimilability $=$ 0.5 (eurihages), or 0.7 (predators). The ratios euriphages to predators in plankton were taken to be 2.7 (mesotrophic waters), and 1 (oligotrophic waters) (Sorokin 1968, Petipa et al. 1971, Shushkina 1977). Using the results of these calculations approximate energy balances in plankton communities of 4 different areas of the central Indian Ocean were computed (Table 9). Corresponding schemes of their energy flow were developed, based on the data listed in Table 9 (Fig. 11).
A

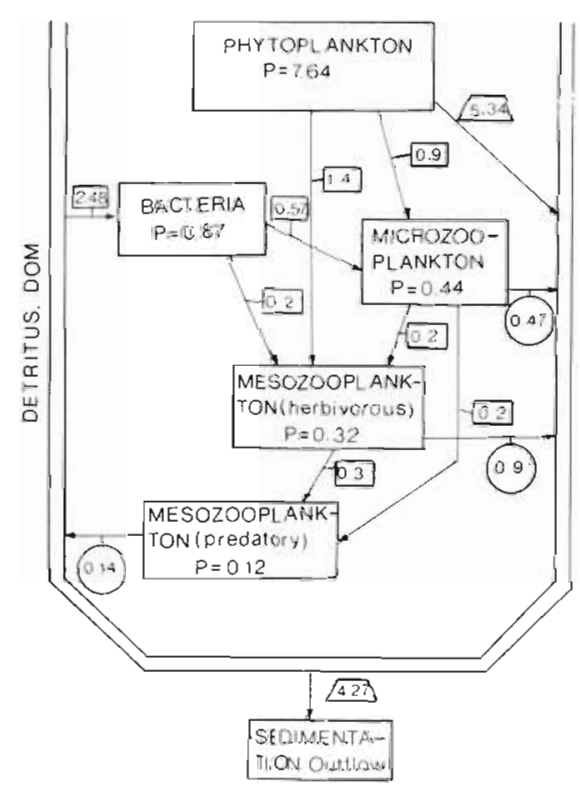

Fig. 11. Schemes of energy balances of planktonic communities in the 0 to $150 \mathrm{~m}$ layer in areas of main surface currents in the central Indian Ocean. (A) Moonson current (St. 2096); (B) Trade Wind Current at $80^{\circ} \mathrm{E}$ (St. 2100); (C) Trade Wind Current, Carlsberg Ridge (St. 2109); (D) South Tropical Convergence, Triple Point (St. 2236). P: production; numbers in squares: rations of subsequent component in the food chain: numbers in circles: non-assimilated food; numbers in trapezia: non-consumed production. All numbers given as $\mathrm{kcal} \mathrm{m}^{-2} \mathrm{~d}^{-1}$
C
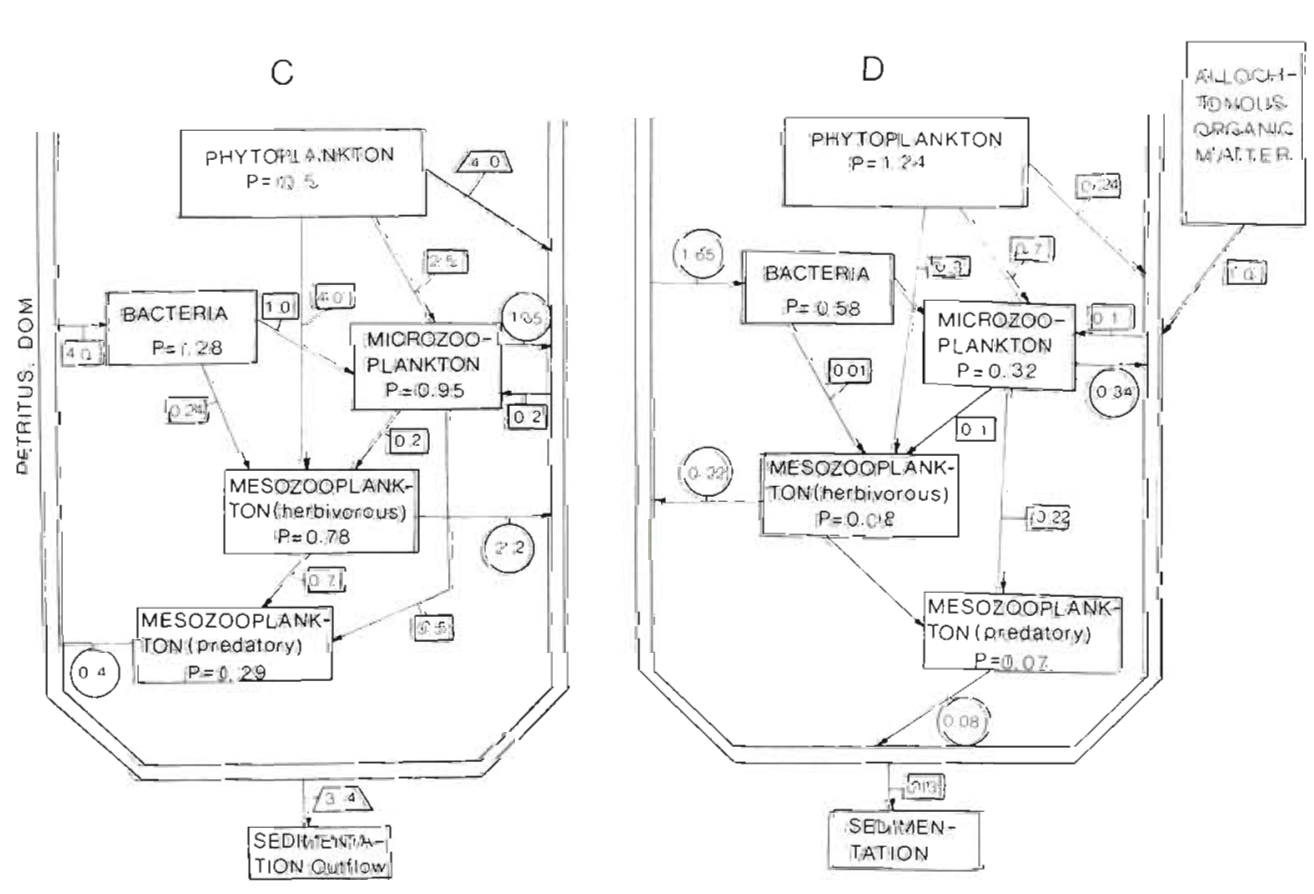

B

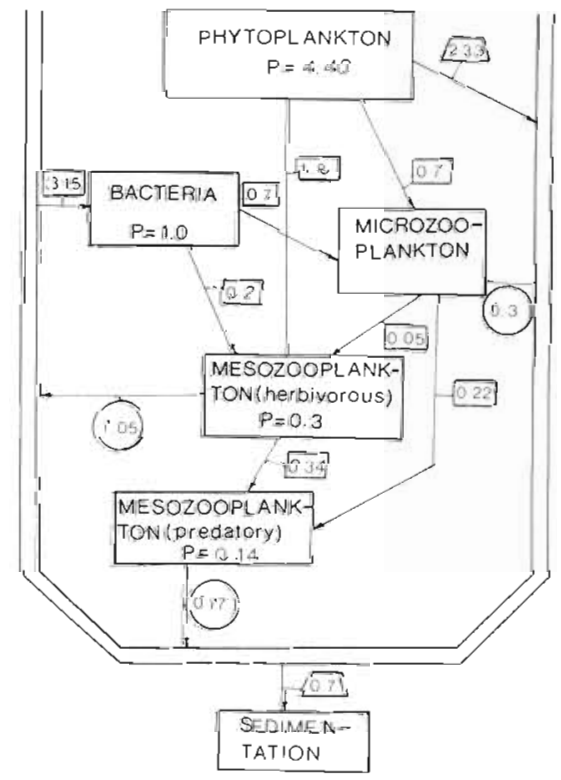


The calculations in Tables $8 \& 9$ and in the schemes of Fig. 11 demonstrate that in areas with a relatively high upper thermocline boundary the primary production at most stations exceeded heterotrophic respiration (Table 8), as well as the total food demand (food ration) of heterotrophes (Table 9; Fig. 11). Sometimes this ratio was as high as 2.5 . The latter ratio is specific to that at the initial (autotrophic) phase of the succession of planktonic communities (Sorokin 1977). This proves that the period of our studies coincided with the biological spring, which actually exists even in tropical regions. In the area of convergence the total destruction of organic matter exceeded primary production. The ration of heterotrophes was satisfied by the primary producers only to $60 \%$. The lack of food could be compensated for only at the expense of additional microbial production which was achieved here by bacteria utilizing external organic matter, brought in from other areas of the World Ocean.

The P/B coefficient of bacterioplankton per day varied from 0.23 to 0.74 . Microbial respiration comprised 40 to $70 \%$ of the total heterotrophic respiration. Thus microbial respiration was usually responsible for more than half, and that of microheterotrophes (bacteria + microzooplankton) for more than $3 / 4$ of the total heterotrophic respiration (total destruction of organic matter). This supports our previous estimations of these ratios in other parts of the ocean (Sorokin 1978).

The data on total heterotrophic respiration (Tables 3 , $4,8 \& 9$ ), facilitate assessments of BOD values (biological oxygen demand), or of the destruction rate per day. Within the euphotic zone it was 5 to $20 \mu \mathrm{g} \mathrm{O} \mathrm{O}^{-1}$ or 1.2 to $3.2 \mathrm{ml} \mathrm{O}_{2} \mathrm{yr}^{-1}$. These values are 2 to 3 times higher than those obtained for the same region by Tchernyakova \& Nalbandov (1981). The latter accounted only for respiration of mesozooplankton, i.e. without that of microheterotrophes. But as was shown above (Table 8), their share in the total respiration was 60 to $80 \%$. In the deep waters below 400 to $500 \mathrm{~m}$, where the biomass of the larger zooplankton decreases 2 orders of magnitude, the share of microheterotrophes will be even much higher (surely more than $90 \%$ ). Therefore $\mathrm{BOD}$ rates calculated without accounting for the respiration of microheterotrophes in the deep waters would underrestimate the true values by an order of magnitude. The above-mentioned authors reported, for example, the following calculated annual BOD values in intermediate and deep waters of the central Indian Ocean (5 to $10^{\circ} \mathrm{S}$ ): ca $0.01 \mathrm{ml} \mathrm{l}^{-1}$ at 500 to $1000 \mathrm{~m}$ depth, and ca 0.002 to 0.003 at 1000 to $2000 \mathrm{~m}$. In accordance with our direct measurements at 500 to $600 \mathrm{~m}$ depth the annual $\mathrm{BOD}$ is not less than $0.1 \mathrm{ml} \mathrm{O}_{2} \mathrm{l}^{-1}$, and at 1000 to $2000 \mathrm{~m}, \mathrm{ca} 0.02 \mathrm{ml} \mathrm{l}^{-1}$. Thus the stock of oxygen in these waters should be sufficient to support the above rates of plankton respiration for 50 to $150 \mathrm{yr}$. This time of turnover of intermedial waters of the ocean seems to be quite realistic

This study proves the assumption that microzooplankters (especially the naked zooflagellates and ciliates) constitute an important component of the planktonic community. Their levels of production and energy expenditure are about the same as those of the mesozooplankters (Tables $8 \& 9$ ). Therefore, without taking into account the microzooplankton, adequate approximations of the energy balance or quantitative evaluations of the trophic conditions in marine pelagic ecosystems seem impossible (see also Beers et al. 1980, Azam et al. 1983).

\section{LITERATURE CITED}

Aruga, Y. (1971). Primary production in the Indian ocean. Internat. Indian Ocean Exped. Abstr., Kiel 31: 18-21

Azam, A. F., Fenchel, T., Field, J. G., Gray, J. S., Meyer-Reil, L. A., Thingtad, F. (1983). The ecological role of waters column microbes in the sea. Mar. Ecol. Prog. Ser. 10: $257-263$

Beers, J. R., Reid, F. M., Stewart, G. L. (1980). Microplankton population structure in Southern California nearshore waters in late spring. Mar. Biol. 60: 209-226

De Vooys, CGN (1979). Primary production in aquatic environments. In: Bolin, B. (ed.) The global carbon cycle. Scope, Surrey, p. 259-290

Eppley R. W. (1981). Autotrophic production of particulate matter. In: Longhurst, A. R. (ed.) Analysis of marine ecosystems, Academic Press, London, p. 343-361

Fournier, R. O. (1970). Studies on pigmented microorganisms from aphotic marine environements. Limnol. Oceanogr. 15: $675-682$

Gitelson, I. I., Levin, L. A., Shevyrnogov, A. P. (1971). Batiphotometric profiles in water column and their use for study of the structure of plankton communities. In: Vinogradov, M. E. (ed.) Functioning of pelagic ecosystems in tropical ocean. Moscow, p. 50-61

Hentschel, E. (1936). Allgemeine Biologie des südatlantischen Ozeans. Erg. Deutsch Atl. Exp. 'Meteor' 11: 1925-1927

Kabanova, Yu. G. (1963). Primary production and nutrients in the Indian Ocean. Trans. Inst. Oceanol. Acad. Sci. USSR 64: $257-264$

Kabanova, Yu, G. (1968). Primary production in the Northern Indian Ocean. Oceanologya (Moscow) 8: 270-278

Kabanova, Yu. G., Borodkin, S. O. (1981). Primary production of the surface waters. In: Biohydrochemistry of the N-W Indian Ocean. Nanka, Moscow, p. 35-40

Koblentz-Mishke, O. J., Volkovinsky, V V., Kabanova, Yu. G. (1970). Plankton primary production in the World ocean In: Wooster, W. (ed.) Scientific exploration of the South Pacific Ocean. Nat. Acad. Sci, Washington, D. C., p. 183-193

Krey, J. (1973). Primary production. In: Zeitzschel, B. (ed.) The biology of the Indian Ocean. Springer-Verlag, New York

Krishnamutthy, K., Santhanam, R. (1975). Ecology of Tintinnida in Porto Novo region. Indian J. mar. Sci. 4: 181-184

Kuzmenko, L. V. (1981). Primary production in central Arabian sea waters, In: Complexnoye issledovanie Indiiskogo Oceana. Mar. Geophyz. Institute, Sebastopol, p. 108-114

Mitzkevich, I. N., Kriss, A. E. (1982). Distribution of the 
number, biomass and production of microorganisms in the World ocean. Int. Revue ges. Hydrobiol. 67: 433-458

Moiseev, P. A. (1969). Biological resources of the world ocean. Moscow

Morita, R. Y. (1972). Pressure: bacteria, fungi and blue-green algae. In: Kinne. O. (ed.) Marine ecology, Vol. I, Environmental factors, Part 3. Wiley, London, p. 1361-1388

Parsad, R. R. (1956). Further studies in the plankton of the inshore waters off Mandapam. Indian. J. Fish. 3: 1-42

Petipa, T. S., Pavlova, E. V., Sorokin, Yu. I. (1971). Studies of the feeding of mass species of plankton of tropical Pacific with the aid of $\mathrm{C}^{14}$. In: Vinogrador, M. E. (ed.) Functioning of pelagic communities in the tropical ocean., Moscow, p. 123-141

Pomeroy, L. R. (1974). Oceanic productivity - a changing paradigm. Bioscience 24: 499-501

Romanenko, V. I. (1964). Heterotrophic assimilation of $\mathrm{CO}_{2}$ by aquatic microflora. Mikrobiologiya (Moscow) 33: 679-683

Ryther, J. H., Hall, J., Pearse, A. K. (1966). Primary organic production in relation to the chemistry and hydrography of the western Indian Ocean. Limnol. Oceanogr. 11: 371-380

Shushkina, E. A. (1977). Production of zooplankton. In: Vinogradov, M. E. (ed.) Biology of ocean. Moscow, 2: 233-247

Sieburth, J. Mc. N., Smetacek, V., Lentz, J. (1978). Pelagic ecosystem structure; heterotrophic compartments of plankton and their relationship to plankton size fractions. Limnol. Oceanogr. 23: 1256-1961

Sorokin, Yu. I. (1960). Vertical distribution of phytoplankton and the primary production in the Sea. J. Cons. perm. int. Explor. Mer 29: 41-65

Sorokin, Yu. I. (1963). Primary production in the Atlantic Ocean. Hydrobiologia 22: 306-316

Sorokin, Yu. I. (1964). Primary production of phytoplankton in the Black Sea. Izvestia Acad. Nauk USSR (Moscow) 5: 749-758

Sorokin, Yu. I. (1968). The use of $\mathrm{C}^{14}$ for study of the nutrition of aquatic animals. Mitt. int. Verein. theor. angew. Limnol. 16: 1-48

Sorokin, Yu. I. (1970). On the estimation of activity of heterotrophic bacteria in the ocean with the use of labelled organic matter. Mikrobiologiya (Moscow) 39: 149-156
Sorokin, Yu. I. (1971). On the role of bacteria in the productivity of tropical oceanic waters. Int. Revue ges. Hydrobiol. 56: $1-48$

Sorokin, Yu. I. (1973). Data on the biological productivity of the western tropical Pacific Ocean. Mar biol. 20: 177-196

Sorokin, Yu. I. (1974). Microbial production in aquatic environments. In: Biological productivity of water bodies. W. Hall \& Co, Boston, Mass., p. 47-107

Sorokin, Yu. I. (1977). The heterotrophic phase of plankton succession in the Japan sea. Mar. Biol. 41:107-117

Sorokin, Yu. I. (1978). Decomposition of organic matter and nutrient regeneration. In: Kinne, $O$. (ed.) Marine ecology, Vol. IV, Dynamics. Wiley, Chichester, p. 501-616

Sorokin, Yu. I. (1979). On the method of concentration of phytoplankton. Hydrobiol. J. (Kiev, USSR) 15: 71-76

Sorokin, Yu. I. (1980). A chamber for the counts of protozoa and nannoplanktonic organisms. Hydrobiol. J. (Kiev, USSR) 16: 84-86

Sorokin, Yu. I. (1981). Marine microheterotrophs. In: Longhorst, H. (ed.) Analysis of marine ecosystems. Academic Press, London, p. 293-342

Sorokin, Yu. I., Kadota, H. (ed.) (1972). Techniques of the assessment of microbial production and decomposition in freshwaters. IBP-Nanual, London, N 23, p. 1-104

Sorokin, Yu. I., Kogelschatz, J. (1979). Analysis of heterotrophic microplankton in upwelling area. Hydrobiologia 66: 195-208

Tchernyakova, A. M., Nalbandov, Yu. P. (1981). Biochemical oxygen consumption. In: Biohydrochemistry of NW-part of the Indian Ocean. Nauka, Moscow, p. 40-45

Troitsky, A. S., Sorokin, Yu. I. (1967). On the methods of calculation of microbial biomass in water bodies. Trans. Inst. Biol. Inland Waters (Borok), Acad. Sci. USSR 19: 85-90

Vinogradov, M. E. (1977). Zooplankton. In: Vinogradov, M.E. (ed.) Biology of the ocean, Moscow, 1: 132-151

Zeitzschel, B. (1969). Tintinnen des westlichen Arabischen Meers. 'Meteor' Forsch. Erg. (D) 4: 47-101 